\title{
Protein recovery as a resource from waste specifically via membrane technology-from waste to wonder
}

\author{
Kanwal Shahid ${ }^{1} \cdot$ Varsha Srivastava $^{2} \cdot$ Mika Sillanpää $^{3,4,5,6}$ \\ Received: 12 February 2020 / Accepted: 29 December 2020 / Published online: 13 January 2021 \\ (C) The Author(s) 2021
}

\begin{abstract}
Economic growth and the rapid increase in the world population has led to a greater need for natural resources, which in turn, has put pressure on said resources along with the environment. Water, food, and energy, among other resources, pose a huge challenge. Numerous essential resources, including organic substances and valuable nutrients, can be found in wastewater, and these could be recovered with efficient technologies. Protein recovery from waste streams can provide an alternative resource that could be utilized as animal feed. Membrane separation, adsorption, and microbe-assisted protein recovery have been proposed as technologies that could be used for the aforementioned protein recovery. This present study focuses on the applicability of different technologies for protein recovery from different wastewaters. Membrane technology has been proven to be efficient for the effective concentration of proteins from waste sources. The main emphasis of the present short communication is to explore the possible strategies that could be utilized to recover or restore proteins from different wastewater sources. The presented study emphasizes the applicability of the recovery of proteins from various waste sources using membranes and the combination of the membrane process. Future research should focus on novel technologies that can help in the efficient extraction of these high-value compounds from wastes. Lastly, this short communication will evaluate the possibility of integrating membrane technology. This study will discuss the important proteins present in different industrial waste streams, such as those of potatoes, poultry, dairy, seafood and alfalfa, and the possible state of the art technologies for the recovery of these valuable proteins from the wastewater.
\end{abstract}

Keywords Purple phototrophic bacteria $\cdot$ Wastewaters $\cdot$ Microalgae $\cdot$ Mesoporous silica nanoparticles $\cdot$ Potato processing waste $\cdot$ Alfalfa processing waste $\cdot$ Dairy waste protein $\cdot$ Membrane fouling

Responsible Editor: Ta Yeong Wu

Kanwal Shahid

kanwal.shahid@lut.fi

1 Department of Separation Science, School of Engineering Science, Lappeenranta-Lahti University of Technology, Sammonkatu 12, FI-50130 Mikkeli, Finland

2 Department of Chemistry, University of Jyväskylä, P.O. Box 35, FI-40014 Jyväskylä, Finland

3 Institute of Research and Development, Duy Tan University, Da Nang 550000, Vietnam

4 Faculty of Environment and Chemical Engineering, Duy Tan University, Da Nang 550000, Vietnam

5 School of Civil Engineering and Surveying, Faculty of Health, Engineering and Sciences, University of Southern Queensland, West Street, Toowoomba, QLD 4350, Australia

6 Department of Chemical Engineering, School of Mining, Metallurgy and Chemical Engineering, University of Johannesburg, P. O. Box 17011, Doornfontein 2028, South Africa

\begin{tabular}{|c|c|}
\hline \multicolumn{2}{|c|}{ Abbreviations } \\
\hline $\mathrm{BCA}$ & Bicinchoninic acid assay \\
\hline CCRSM & Central combined response surface methodology \\
\hline COD & Chemical oxygen demand \\
\hline CES & Carboxyethylsilanetriol sodium \\
\hline $\mathrm{CF}$ & Concentration factor \\
\hline DOC & Dissolve organic carbon \\
\hline EAAI & Amino acid index \\
\hline EBA & Expanded bed adsorption \\
\hline HOBs & Hydrogen-oxidizing bacteria \\
\hline $\mathrm{kDa}$ & Kilodalton \\
\hline MWCO & Molecular weight cut-off \\
\hline $\mathrm{mg} / \mathrm{L}$ & Milligramme per litre \\
\hline MF & Microfiltration \\
\hline $\mathrm{NH}_{4}-\mathrm{N}$ & Ammonium \\
\hline NF & Nanofiltration \\
\hline $\mathrm{nm}$ & Nanometre \\
\hline PES & Polyethersulfone \\
\hline
\end{tabular}




$\begin{array}{ll}\text { PPB } & \text { Purple phototrophic bacteria } \\ \text { PSB } & \text { Photosynthetic bacteria } \\ \text { PO }_{4} \text {-P } & \text { Phosphate } \\ \text { PFJ } & \text { Potato fresh juice protein } \\ \text { PPW } & \text { Potato processing wastewater } \\ \text { RO } & \text { Reverse osmosis } \\ \text { RDM } & \text { Rotating disk membrane } \\ \text { SBA } & \text { Santa Barbara Amorphous } \\ \text { SCOD } & \text { Soluble chemical oxygen demand } \\ \text { SCP } & \text { Single-cell protein } \\ \text { SWH } & \text { Subcritical water hydrolysis } \\ \text { TKN } & \text { Total Kjeldahl nitrogen } \\ \text { TN } & \text { Total nitrogen } \\ \text { TP } & \text { Total phosphorus } \\ \text { TMP } & \text { Transmembrane pressure } \\ \text { TS } & \text { Total solids } \\ \text { UF } & \text { Ultrafiltration } \\ \text { VMD } & \text { Vacuum membrane distillation } \\ \mu m & \text { Micrometre }\end{array}$

\section{Introduction}

The most important driving force for recovering nutrients from wastewater during the treatment is the increasingly limited accessibility of resources. Population growth, fertilizer use, agricultural restrictions, soil erosion, and extreme weather events have had drastic effects, including malnutrition resulting from protein shortage. Globally, protein for animal feed is not sufficiently available; in order to meet this demand, many countries rely on the import of feed protein. At present, soybean protein (imported from other countries) serves as the main share of protein nourishment in animal feeding in Europe (Yin et al. 2011). A shortage of protein can be overcome through the optimisation of local protein resources based on the elevation of biomass concentration, especially from green plants. Inherent nutrient loss usually occurs in the upscaling of plant proteins to animal proteins, leading to the revival of the traditional idea of upgrading the manufacturing of microbial protein. The extraction of proteins from wastewater along with other resources could be an attractive low-cost alternative (Van Der Hoek et al. 2016). The wastewaters of several industries, including leather processing, contain significant concentrations of important proteins such as albumins and globulins. Furthermore, the meat processing industry together with sheep, cattle and poultry processing factories are also known to release high amounts of proteins into wastewater (Jayathilakan et al. 2012). The recovery and removal of proteins from wastewater has advantages, as these proteins are in demand for the manufacture of medicines and food additives. Such a procedure would also purify the wastewater for later use. The main issue is not the availability of resources and technology, but rather the deficiency in properly devising a structural plan and methodology to recognize the most balanced solution in a certain geographical framework (Guest et al. 2009). Various concepts have been implemented for the recovery of proteins from a waste stream, such as single-cell protein (SCP), purple phototrophic bacteria (PPB) (Meng et al. 2018) and microalgae culture (Hülsen et al. 2018). Recent research has been focused on finding the potential sources for protein recovery from sludge, grass and the wastewater of various industries. Membrane technology and adsorption have been studied for protein recovery from wastewater (Chen et al. 2007; Dabestani et al. 2017), but there is still a need to develop an efficient way to recover proteins from the waste stream. An overview of potential sources of proteins and their recovery approaches are discussed in the present study, which also gives a summary of the advances in upgrading protein waste to produce valuable materials that are prominent on technological platforms.

\section{Protein recovery by different approaches}

\section{Protein recovery concept as single-cell protein (SCP)}

The concept of the production of SCP is well-known, and it is a feasible way of rapidly reducing the environmental footprint. As large amounts of protein and a wide range of substrates can be converted into it (Matassa et al. 2015), SCP is therefore considered the most efficient way of recovering nitrogen from waste sources using heterotrophic bacteria and algae. SCP also has the potential to enable the bio-based circular economy. With this method, the invested nitrogen can be restored from the environment and accumulated in the form of microbial protein from a waste medium (Shi et al. 2007; Hülsen et al. 2014). SCP is hindered by its production cost, which needs to decrease in order to enable practical implementation and compete with agricultural alternatives. The main cost input in SCP production is the carbon source, but this can be minimized by using industrial waste streams such as flue gas. Due to the production of SCP, the organic contents present in the wastewater are recycled through assimilative segregation despite being lost or consumed as carbon dioxide and nitrogen gas into the air (Batstone et al. 2015).

Many researchers have tried to recover proteins using different waste media (water from several sources). The potential of purple phototrophic bacteria (PPB) and microalgae to treat diverse waste streams from agricultural and industrial sources was investigated by (Hülsen et al. 2018). PPB and microalgae are two important intermediates in the production of SCP. Microalgae are responsible for manufacturing protein-rich feed substitutes for both humans and animals (Sangameshwar Barnes et al. 2013). In the case of PPB, the utilization of infrared light has been more efficient in the production of high yields (Hülsen et al. 2014). Several 
researchers have focused on the removal of COD with PPB from synthetic, sterilized, and diluted wastewaters, but little is known about real wastewaters (Nagadomi et al. 2000). It can be concluded that until now there has been little focus on the removal of COD, nitrogen and phosphorus from industrial waste streams along with SCP recovery. In a recent study, diverse varieties of both PPB and algae were used to treat actual industrial and agricultural wastewaters. The important comparisons were taken into considerations that include the composite concurrent non-destructive simultaneous assimilation of COD along with nitrogen and phosphorus. The achieved yield of SCP was then estimated. The obtained discoveries can be applied to understand the possible manufacturing of single-cell proteins in our prime trades, with a focus on the newly evolving association between nutrients, energy, water and the environment (Hülsen et al. 2018).

The treatment efficiency of different industrial wastewaters with PPB and microalgae was determined by measuring parameters such as soluble COD, the concentration of ammonium and phosphate, elimination of nitrogen and total chemical oxygen demand to evaluate the removal abilities. For example, in the case of poultry wastewater treatment, PPB actively removed COD (in soluble form) along with ammonium and phosphate in a ratio of 100: 11: 1.6, respectively. The performance of PPB for the treatment of pork flesh and dairy wastewaters was reasonable but overcoming losses of organic matter is a question that still needs to be taken into consideration. However, the wastewater from the sugar industry had a higher COD value. Treating this by microalgae and PPB proved to be noxious as negligible removal of soluble amounts of COD, $\mathrm{NH}_{4}-\mathrm{N}$ or $\mathrm{PO}_{4}-\mathrm{P}$ was observed. Nevertheless, the author concluded that the microalgae tests achieved better removal efficiency of SCOD, $\mathrm{NH}_{4}-\mathrm{N}$ and $\mathrm{PO}_{4}-\mathrm{P}$ overall than PPB. The most satisfactory results were obtained with poultry wastewater treatment with $91 \pm 18 \%$ COD removal, along with $91 \pm$ $29 \%$ and $73 \pm 27 \%$ of nitrogen and phosphorus removal, respectively (Khosravi-Darani et al. 2013).

The researcher also tried to characterize the biomass formed in the treatment of different waste streams. It was estimated that PPB biomass had an elevated protein content (based on solid Total Kjeldahl Nitrogen (TKN)) (Eding et al. 2006). The concentration of protein was estimated with the bicinchoninic acid assay (Ras et al. 2008). The crude protein content obtained in the present study corresponds well with other reported inquiries (Ponsano et al. 2004). The large harvest protein shows the integration of organics and nitrogen without any dissimilation (Kim et al. 2005). It was concluded that PPB and microalgae can serve as a responsible mediator for upgrading and recycling the nutrients from wastewater (Hülsen et al. 2018). A study related to the recovery of resources from wastewater was published in order to understand the production capabilities of hydrogen-oxidizing bacteria (HOBs) (Matassa et al. 2015). It covers the recovery of nutrients from wastewaters and the use of the recovered products as a starting material for the synthesis of valued biomaterials. It also elaborates on the competence of hydrogenoxidizing bacteria to elevate the raw nitrogen and minerals into a significant microbial product. Mutually isolated and mixed diverse microbial cultures can be utilized for the tailored synthesis of restored biological compounds into complex biomolecules. It is already known that HOBs are believed to be the utmost influential contributors to the overview of biorefineries. Hydrogen-oxidizing or Knallgas bacteria (so called as they utilize gaseous hydrogen and oxygen) are autotrophic bacteria. This prominent feature gives these microorganisms numerous dietary competencies over others, including the ability to survive in a solely inorganic environment along with reducing nitrogen into new cells and more conversion of carbon dioxide (Repaske and Mayer 1976). Innovative tactics using these bacteria may have the potential to improve the nutrients restored from anaerobic digestion and waters rejected in water treatment plants during the carbon dioxide fixation process and enhance conversion activity towards biomethane. Although a sustainable and effective alternative to photosynthetic biomass construction, $\mathrm{HOBs}$ are viewed as a possible supplier of the microbial product in the form of SCP. The feasibility of HOBs as SCP manufacturers was later explored in a report on the properties of the proteins created by the microbes (Volova and Barashkov 2010). The biological value of proteins made by three strains of HOBs was evaluated. These strains are as follows: Alcaligenes eutrophus Z1, Ralstonia eutropha B5786, and the carbon monoxide resistant strain carboxydobacterium Seliberia carboxydohydrogena Z1062. The work indicated a massive amount of protein synthesized by the above-mentioned species, along with the sequences of essential amino acids. Certainly, the amino acids are more likely those of yeast, but, at about $70 \%$, the ultimate concentration of protein, also known as dry weight in the case of hydrogen-oxidizing bacteria, is much higher than that of other species (50\% in the case of yeast) (Anupama 2000).

\section{Protein recovery by the advance one-step photosyn- thetic bacteria (PSB) method}

Researchers established a method known as the one-step photosynthetic bacteria (PSB) process to efficiently remove pollutants and recover nutrients from high-COD, non-toxic wastewaters (Meng et al. 2018). PSB is well-known as a collection of bacteria that can harvest light energy to pursue both the autotrophic and heterotrophic processes (Cao et al. 2020). Being state-of-the-art, PSB can efficiently treat wastewater such as that from the fish industry (Azad et al. 2004), wastewater containing starch (Getha et al. 1998; Prachanurak et al. 2014), dairy industry wastewater (Kaewsuk et al. 2010), rubber manufacturing industry wastewater, livestock waste streams (Ponsano et al. 2008), and domestic waste streams 
(Nagadomi et al. 2000; Hülsen et al. 2018). The possible elimination of COD (up to 85-93\%) and ammonia nitrogen removal (99\%) is likely to be obtained (Saejung and Thammaratana 2016; Yang et al. 2017). PSB biomass is a sound source of single-cell protein that can act as a feed for sealife. This high-grade feed effectively promotes body growth, along with an improvement in disease tolerance, with its advanced water value. PSB cells also contain carotenoids and coenzyme Q10 (CoQ10) (Hao et al. 2017). Unlike algae technology, PSB can handle wastewater with low nitrogen and phosphorous, but they cannot cope with wastewater with a high COD value. PSB technology is better in treating wastewater with a high COD content, such as the wastewater obtained from starch processing companies (potato, corn and wheat), which has a COD value of approx. 10,000 mg/L. However, PSB technology has the potential to treat this water along with a biomass harvest of up to $0.51 \mathrm{mg}$ of biomass per milligramme of biological oxygen demand removal (Prachanurak et al. 2014). Different strains of PSB, additives, and different valuable substances were used to examine biomass growth. There was an attempt to use synthetic wastewater that could mimic characteristics such as COD, total nitrogen, and phosphorus concentration in brewery wastewater. The estimated measured qualities of wastewater are as follows: COD (2200-2600), total nitrogen (20-22), and total phosphorus (5-6 mg/L) (Meng et al. 2018). The characteristics of wastewater, such as the removal efficiency of the COD, total nitrogen and phosphorus (TP) and production of biomass as the value of observance with time duration using the PSB strain, are shown in Table 1 (Chen et al. 2020).

As the preliminary COD concentration of the brewery wastewater was approx. $2200 \mathrm{mg} / \mathrm{L}$, it can be observed from Table 1 that PSB could successfully reduce the chemical oxygen demand of a given waste stream by up to $800 \mathrm{mg} / \mathrm{L}$ after $72 \mathrm{~h}$ along with a significant reduction in the concentration of nitrogen, but it is less effective for the removal of phosphorus. The biomass increased over time and has its applications, such as active use as a fertilizer. This method is understood to be effective for concurrent nutrient recovery and waste treatment. However, as the final COD was still very high at $800 \mathrm{mg} / \mathrm{L}$, it was outside the stated disposal range of $80 \mathrm{mg} / \mathrm{L}$. There is, therefore, a need for more intense research to expand COD removal with treatment by the PSB strain. The researcher tried yeast extract as a distinctive active organic nutrient substitute, along with other additives such as magnesium and iron (Zhang et al. 2015a; Zhi et al. 2020).

The result in Table 2 shows that all three additives effectively improve the removal efficiency of COD, but the performance of yeast extract is more pronounced. As far as the composition of the yeast extract is concerned, it contains nitrogen (amino acids) and some minerals (copper and iron). The presence of these compounds may influence COD reduction. The enhanced COD removal of up to $96.7 \%$ was obtained when the concentration of yeast extract was increased to $400 \mathrm{mg} / \mathrm{L}$ (Table 3).

As stated earlier, the main benefit of using PSB for wastewater handling is that it can produce an interesting amount of PSB biomass, which is a rich source of protein along with other biopolymers. With these abilities, researchers studied the composition of produced biomass growth and its valuable components.

The main breakthrough in this field is that PSB worked in the treatment of the brewery waste stream. It was also able to produce highly valued PSB cells with the dischargeable COD value of the final stream, which is a value that conforms to the national release value so that there is no need for any posttreatment. The Rhodopseudomonas strain is the most efficient one. The obtained PSB cells were a rich source of the desired protein along with other biopolymers such as polysaccharides, carotenoids and coenzyme Q10. The concentration of the PSB cell protein increased to approx. $420.9 \mathrm{mg} / \mathrm{g}$ after the reaction (Qi et al. 2017).

\section{Protein recovery from plant biomass}

Dotsenko and Lange investigated the recovery of protein from two different sources: white clover and ryegrass screw pulps. They applied the extraction technique in the presence of aqueous media, also with enzymes such as carbohydrases and proteases to promote extraction behaviour (Dotsenko and Lange 2017). To date, protein extraction from biomass pulp has been unexplored, and more focus has been centred on protein recovery from leaves, primarily by mechanical disintegration. There is a need to upgrade the process of protein recovery from leaves and the pulp. The pioneer of the extraction of proteins from leaves is Pirie, who recommended the fragmentation of fresh green biomass mechanically, leading to
Table 1 Characteristics of wastewater (chemical oxygen demand, total nitrogen, total phosphorus) and production of biomass as the value of observance with time duration using the PSB strain (Meng et al. 2018; Chen et al. 2020)

\begin{tabular}{lllll}
\hline $\begin{array}{l}\text { Time } \\
(\mathrm{h})\end{array}$ & $\begin{array}{l}\text { Chemical oxygen demand } \\
(\mathrm{mg} / \mathrm{L})\end{array}$ & $\begin{array}{l}\text { Total nitrogen } \\
(\mathrm{mg} / \mathrm{L})\end{array}$ & $\begin{array}{l}\text { Total phosphorus } \\
(\mathrm{mg} / \mathrm{L})\end{array}$ & $\begin{array}{l}\text { Total Biomass } \\
\left(\mathrm{OD}_{660}\right)\end{array}$ \\
\hline 0 & $\sim 2200$ & $\sim 17$ & $\sim 5$ & $\sim 0.3$ \\
24 & $\sim 1400$ & $\sim 3.8$ & $\sim 4.7$ & $\sim 0.5$ \\
48 & $\sim 1000$ & $\sim 3$ & $\sim 4.3$ & $\sim 0.62$ \\
72 & 800 & $\sim 2.5$ & $\sim 4.1$ & $\sim 0.78$ \\
\hline
\end{tabular}


Table 2 COD removal efficiency with three different additives (yeast extract, magnesium and iron) with PSB cells with time duration in wastewater treatment (Sasaki et al. 2012; Wen et al. 2016)

\begin{tabular}{llll}
\hline Time & Yeast extract & $\begin{array}{l}\text { Magnesium } \\
\text { COD }(\mathrm{mg} / \mathrm{L})\end{array}$ & $\begin{array}{l}\text { Iron } \\
\text { COD }(\mathrm{mg} / \mathrm{L})\end{array}$ \\
\hline 0 & $\sim 2300$ & $\sim 2200$ & $\sim 2200$ \\
24 & $\sim 1750$ & $\sim 1550$ & $\sim 1650$ \\
48 & $\sim 950$ & $\sim 1070$ & $\sim 1000$ \\
72 & $\sim 500$ & $\sim 800$ & $\sim 700$ \\
\hline
\end{tabular}

separation of the protein from the obtained juice of biomass (Fiorentini and Galoppini 1983).

Several physical and chemical techniques for the separation and purification of protein from the leaves of plants were proposed, but the most relevant methods used for the separation of protein from cellulose-containing biomass are via alkali (Zhang et al. 2014a), aqueous ammonia extraction, and mechanical disintegration of biomass. The main hypothesis of the work done by (Dotsenko and Lange 2017) is that, after screw-pressing the green leaves, a significant proportion of the protein content is left over in the pulp portion, and that protein can be used to feed animals in different ways. The pulp part of green leaves can be used to feed cows, and with the hydrolysis process it can be used as additives in the preparation of food for other animals such as pigs, chickens and fish. The results obtained from their work showed that, by applying the extraction at $\mathrm{pH} 8.0$ on the pulp portion of the leaves, roughly $40 \%$ of the total pulp protein was improved and $80 \%$ of the protein was restored by proteases (Savinase 16.0 L, Novozymes), depending on the dose of this enzyme. The action of enzyme carbohydrases (Cellic CTec2 and Cellic HTec2, Novozymes) on pulp hydrolysis did not yield any significant production of protein (Kinsella 1988).

\section{Protein recovery by adsorption}

To date, researchers have been focusing on the development of efficient adsorbents for the immobilization of protein, as there is a crucial need for the fruitful implementation of its applications in different areas. The selection of an appropriate adsorbent for the adsorption of protein depends on several factors, including surface area and large pore sizes with a volume ratio that can be placed on proteins and enzymes with ease (Han et al. 2007; He and Shi 2011; Hartmann and Kostrov 2013; Mohammad 2013; Gascón et al. 2014; Masuda et al. 2014; Deka et al. 2015; Tu et al. 2016). Numerous categories of mesoporous silica substances including MCM-41 (Salis et al. 2009), SBA-15 (Washmon-Kriel et al. 2000), MCF and FMS (Kim et al. 2005) have been effectively used for the immobilization of different substances, e.g. proteins and enzymes (enzymes are mostly protein in nature) as supports or base material.

The biggest drawback in the proper implementation of these porous materials is the restriction in the distribution and movements of adsorbed substances due to the small pore sizes and the inner two-dimensional structural design of these pores. Because of the two-dimensional architecture of the pore size, the researcher proposed new mesoporous silica materials as an adsorbent for proteins. These materials are responsible for exclusive pore availability for adsorbates (proteins and enzymes) due to their interrelated pore assemblies, so they efficiently improve adsorption ability. Still, the practical application of these materials in the immobilization of biomolecules brings complications, as there is a hindrance linked to the mesoporous silica due to its electronically neutral silica skeleton. However, the efficiency of silica-based adsorbents can be enhanced by the surface modification of this mesoporous silica by setting organic functional groups such as the carboxylic (-COOH), phenyl, vinyl, and amine groups for the formation of active sites for the adsorbates (protein/enzymes) (Ramasamy et al. 2019). The introduction of these organic groups on the plane of mesoporous material can efficiently minimize the leaching effect of the adsorbed enzymes (Chong et al. 2004; Maria Chong and Zhao 2004; Wang et al. 2006; Sae-ung and Boonamnuayvitaya 2008; Johari et al. 2014).

A recent study led to the manufacture of silica-based mesoporous Santa Barbara Amorphous (SBA-1) type 1 nanoparticles, which possess a distinctive pattern and surface characteristics. Their practice as grounds for the immobilization of papain is described. In this study, different pore sizes of these mesoporous silica particles were synthesized using the carboxylic functional group by means of co-condensation (Lin et al. 2017). Carboxyethylsilanetriol sodium salt (CES) was added for the integration of carboxyl functional groups as a functional moiety.
Table 3 The outcome of different yeast concentrations on removal effectiveness of chemical oxygen demand with time duration (Dikshit and Moholkar 2016; Meng et al. 2018)

\begin{tabular}{lllll}
\hline $\begin{array}{l}\text { Time } \\
(\mathrm{h})\end{array}$ & $\begin{array}{l}\text { Yeast concentration } \\
50 \mathrm{mg} / \mathrm{L}\end{array}$ & $\begin{array}{l}\text { Yeast concentration } \\
100 \mathrm{mg} / \mathrm{L}\end{array}$ & $\begin{array}{l}\text { Yeast concentration } \\
250 \mathrm{mg} / \mathrm{L}\end{array}$ & $\begin{array}{l}\text { Yeast concentration } \\
400 \mathrm{mg} / \mathrm{L}\end{array}$ \\
\hline 0 & $\sim 2250$ & $\sim 2270$ & $\sim 2300$ & $\sim 2450$ \\
24 & $\sim 1750$ & $\sim 1750$ & $\sim 1470$ & $\sim 1510$ \\
48 & 1100 & $\sim 930$ & $\sim 580$ & $\sim 600$ \\
72 & $\sim 700$ & $\sim 500$ & $\sim 150$ & $\sim 80$ \\
\hline
\end{tabular}


The existence of carboxylic functional groups in the mesoporous silica SBA-1 template was validated by an FTIR analysis and $\mathrm{C}^{13}$ solid-state NMR spectroscopy (Saikia et al. 2019a). The prepared mesoporous silica nanoparticles were employed as support for the immobilization experiments of papain protein. The obtained results clearly show that largepore nanoparticles with carboxylic functionality are optimal for the immobilization of the desired protein at the higher end. The major factor behind this immobilization is probably the development of electrostatic interaction between the desired protein and function groups introduced at the surface of the mesoporous nanoparticles. It was reported that modified adsorbent can remove selected proteins from the mixture of protein according to their isoelectric points (Saikia et al. 2019a).

There is great attention towards the extraction, separation, and purification of proteins from composite biological mixtures. In this regard, several methodologies, such as affinity chromatography, precipitation, extraction, and solid-phase extraction, have been developed to segregate the chosen proteins from biological systems (McDonald et al. 2009).

As mentioned in the above example, silica-based support (Iftekhar et al. 2017) with the carboxylic functional group provides proof of the separation of protein from the mixture. It was found that amino acid can also act as an appropriate and efficient ligand in building the networking among proteins or peptides because of the existence of additional functional groups including amine, carboxyl, and tryptophan (Qiao et al. 2018). The researcher tried to incorporate the tryptophan into the silica nanoparticles used as support using crosslinking (Beena et al. 1994). Tryptophan is a hydrophobic amino acid because it consists of an aromatic ring in its side chain, which provides supplementary motive power, primarily pi- pi interactions that help in protein adsorption. They are used to concentrate on Ova proteins that are present in albumin in chickens. The adsorption behaviour of this protein onto the complex silica nanoparticles with tryptophan as a functional group was observed at different $\mathrm{pHs}$ ranging from 3 to 8 . The results obtained showed that the adsorption of the desired protein increases by up to $1240.3 \mathrm{mg} / \mathrm{g}$ compared to its adsorption on unmodified silica nanoparticles, which is $727.6 \mathrm{mg} / \mathrm{g}$. The adsorption operation of the complex material is accredited to the interaction of both pi-pi and hydrogen bonding between the desired protein moiety and adsorbent (Qiao et al. 2018). Table 4 is about the studies presented in the state of the art about the types of adsorbents used for the recovery of specific proteins at given parameters.

\section{Other methods for recovery of protein from different waste sources}

Different studies have been done in the past for the extraction of valuable protein products from different wastes (Table 5). For example, the recycling of meat waste has a significant impact on our environment. The study proposed by (Ghosh et al. 2019) includes the use of electric pulses of different voltages and time duration for the chemical extraction of protein present in the wasted chicken breast muscles. The extracted protein from the waste breast muscle exhibits the antioxidant properties as suggested by the Silico analysis (Ghosh et al. 2019). Other studies indicate the recovery of several types of peptides and proteins from the food waste using the subcritical water hydrolysis (SWH) method (Marcet et al. 2016). For example, the application of the sub-critical hydrolysis process using specific parameters, such as type of reactors, optimum temperature, and reaction time waste obtained from fish entrails, recovered $137 \mathrm{mg} / \mathrm{g}$ of dry fish (Kang et al. 2001). In other studies, the application of SWH on scallop viscera waste leads to the production of important high molecular compounds as well as amino acids (Tavakoli and Yoshida 2006). In the aqueous phase, the best yield of the simplest amino acid comes from glycine (Kaspar and Reichert 2013). The recovery of $91 \%$ protein named Astaxanthin found in shrimp shell waste by enzymatic conversion was performed by (Deng et al. 2020) along with the recovery of other by-products such as chitin. The recovery of collagen protein powder separated from chromium leather scrap waste was studied, revealed to be containing different amino acids and displaying a low concentration of mineral salt that can be used as fertilizer (Dang et al. 2019). A huge amount of waste is produced by the dairy industry, such as whey, the main by-product that is produced during the production of cheese from milk, which is also an abundant source of valuable proteins (Gopinatha Kurup et al. 2019; Tham et al. 2019). The combination process of ultrafiltration and nanofiltration membranes has been used to obtain up to $90 \%$ of proteins from whey waste along with lactose under defined parameters (Das et al. 2016).

\section{Protein recovery by membrane technology}

Membrane technology has been utilized and commercialized to regain valuable substances including proteins from different wastewaters such as potato processing wastewater (PPW) (Dabestani et al. 2017), poultry processing wastewater (Lo et al. 1997), alfalfa wastewater. and dairy waste streams. Different membrane processes including microfiltration (MF), ultrafiltration (UF), and reverse osmosis (RO) have been extensively applied in dairy-producing companies to isolate different components such as casein and proteins from their waste streams (Harmen J.Zwijnenberg et al. 2002). 
Table 4 Protein recovery employing immobilization or adsorption on different supports

\begin{tabular}{|c|c|c|c|c|c|c|c|}
\hline No. & Adsorbent & Protein & $\mathrm{pH}$ & $\begin{array}{l}\text { Temperature } \\
\left({ }^{\circ} \mathrm{C}\right)\end{array}$ & $\begin{array}{l}\text { Time } \\
\text { (mins) }\end{array}$ & $\begin{array}{l}\text { Adsorption } \\
\text { capacity } \\
(\mathrm{mg} / \mathrm{g})\end{array}$ & Reference \\
\hline 1 & $\begin{array}{l}\text { Tryptophan modified aminated mesoporous silica } \\
\text { nanoparticles }\end{array}$ & Ova Protein & 5.0 & ambient temperature & 25 & $\begin{array}{l}1240.3 \\
(96 \%)\end{array}$ & (Qiao et al. 2018) \\
\hline 2 & $\begin{array}{l}\text { Silica (mesoporous) nanoparticles (MSNs) with the } \\
\text { SBA-1 moiety, functional group (-COOH) }\end{array}$ & Papain & 8.2 & ambient temperature & 1600 & 1138 & (Saikia et al. 2019b) \\
\hline 3 & $\begin{array}{l}\text { Cage-type cubic mesoporous silica functionalized } \\
\text { with }(-\mathrm{COOH})\end{array}$ & Lysozyme & 9.6 & 37 & 4800 & 895 & (Deka et al. 2015) \\
\hline 4 & Mesoporous silica nanoparticles (MSNs) & Haemoglobin & 7.4 & ambient temperature & 20 & 747.5 & (Tu et al. 2016) \\
\hline 5 & $\begin{array}{l}\text { Mesoporous silica nanoparticles (MSNs) function- } \\
\text { alized by 3-aminopropyltriethoxysilane }\end{array}$ & Catalase & - & ambient temperature & 20 & $\sim 840$ & (Tu et al. 2016) \\
\hline 6 & SBA-15 & $\begin{array}{l}\text { Bovine serum } \\
\text { albumin }\end{array}$ & 4.8 & 30 & - & 482 & $\begin{array}{l}\text { (Maria Chong and } \\
\text { Zhao 2004) }\end{array}$ \\
\hline 7 & SBA-15 & Lysozyme & 10.6 & ambient & 240 & 636 & (Ma et al. 2017) \\
\hline 8 & Mesoporous silica materials (pore size $17.6 \mathrm{~nm}$ ) & Cellulose & 5.0 & 50 & 600 & 410 & (Kim et al. 2005) \\
\hline
\end{tabular}

\section{Protein recovery from wastewater of the potato processing industry by membrane technology}

Patatin is the main protein of potato wastewater and well known for its good functionality. The protein possesses many important features, including a molecular weight of around 40-45 $\mathrm{kDa}$ along with an amino acid index (EAAI) of about $89 \%$, which is comparatively high compared to that of many other proteins present in plants and animals (Pouvreau et al. 2001; Strætkvern and Schwarz 2012).

Traditionally, there has been a diverse list of techniques for obtaining this valuable protein from potato fruit juice. The most applied techniques were concentration, coagulation with heat, precipitation, ion-exchange chromatography, and ion exchange using Expanded Bed Adsorption (EBA), and many more techniques were used to restore protein from potato fruit juice (PFJ). These approaches have been proven to obtain a high yield percentage of protein, but some processes, such as the application of heat and a harsh environment like acid or alkali, have been unsuccessful in recovering completely intact (non-denatured) high-quality protein (Løkra et al. 2008).

Figure 1 shows the PPW production and collection point, while Fig. 2 illustrates the composition of the process water collected from the source (Dabestani et al. 2017). Several

Table 5 Different waste sources for recovery of protein using different methods

\begin{tabular}{|c|c|c|c|c|c|c|c|}
\hline No. & Waste source & $\begin{array}{l}\text { Types of } \\
\text { protein }\end{array}$ & Method of recovery & $\%$ Recovery & Advantages & Disadvantages & Reference \\
\hline 1 & $\begin{array}{l}\text { Expired dairy } \\
\text { products }\end{array}$ & Milk protein & $\begin{array}{l}\text { Liquid } \\
\text { biphasic flotation } \\
\text { (LBF) method }\end{array}$ & $\sim 94$ & $\begin{array}{l}\text { Waste reduction, } \\
\text { environmental } \\
\text { benefits }\end{array}$ & $\begin{array}{l}\text { Recycling is needed as } \\
\text { the use of alcohol and } \\
\text { high salt conc. }{ }^{1}\end{array}$ & $\begin{array}{l}\text { (Tham et al. } \\
\text { 2019) }\end{array}$ \\
\hline 2 & $\begin{array}{l}\text { Slaughterhouse } \\
\text { blood }\end{array}$ & $\begin{array}{l}\text { Haemoglobin } \\
\text { peptides }\end{array}$ & $\begin{array}{l}\text { Enzymes and } \\
\text { high hydrostatic } \\
\text { pressures (HHPs) }\end{array}$ & $\sim 84$ peptides yield & $\begin{array}{l}\text { Antioxidant and } \\
\text { functional } \\
\text { properties, } \\
\text { cheaper and } \\
\text { simpler method }\end{array}$ & - & $\begin{array}{l}\text { (Álvarez et al. } \\
\text { 2012; Marcet } \\
\text { et al. 2016) }\end{array}$ \\
\hline 3 & $\begin{array}{l}\text { Waste from the } \\
\text { poultry } \\
\text { process }\end{array}$ & Amino acid & $\begin{array}{l}\text { Subcritical water } \\
\text { technology }\end{array}$ & $\sim 11.4$ & $\begin{array}{l}\text { High production } \\
\text { yield along with } \\
\text { energy }\end{array}$ & Chemical usage & $\begin{array}{c}\text { (Zhu et al. } \\
\text { 2010) }\end{array}$ \\
\hline 4 & $\begin{array}{l}\text { Waste activated } \\
\text { sludge }\end{array}$ & $\begin{array}{l}\text { Proteins from } \\
\text { sludge } \\
\text { flocs }\end{array}$ & $\begin{array}{l}\text { Thermal alkali } \\
\text { hydrolysis (TAH) }\end{array}$ & $\sim 67.5$ & $\begin{array}{l}\text { High yield of } \\
\text { solubilized } \\
\text { protein is } \\
\text { obtained }\end{array}$ & $\begin{array}{l}\text { Some protein loss in the } \\
\text { form of ammonium } \\
\text { and nitrates }\end{array}$ & $\begin{array}{l}\text { (Song et al. } \\
\text { 2019) }\end{array}$ \\
\hline 5 & Rohu fish waste & $\begin{array}{l}\text { Protein from } \\
\text { fish waste } \\
\text { source }\end{array}$ & $\begin{array}{l}\text { pH Shift } \\
\text { Method }\end{array}$ & $\begin{array}{l}31.8 \text { via acid } \\
\text { method/ } 31.1 \text { via } \\
\text { the alkaline meth- } \\
\text { od }\end{array}$ & $\begin{array}{l}\text { Isolates via alkaline } \\
\text { methods were } \\
\text { more rigid }\end{array}$ & $\begin{array}{l}\text { Protein with good yield } \\
\text { and functionality after } \\
\text { recovery }\end{array}$ & $\begin{array}{l}\text { (Surasani et al. } \\
\text { 2017) }\end{array}$ \\
\hline
\end{tabular}

${ }^{1}$ conc. concentration 
Fig. 1 presents potato chips production and point of wastewater collection (Dabestani et al. 2017; Fritsch et al. 2017)

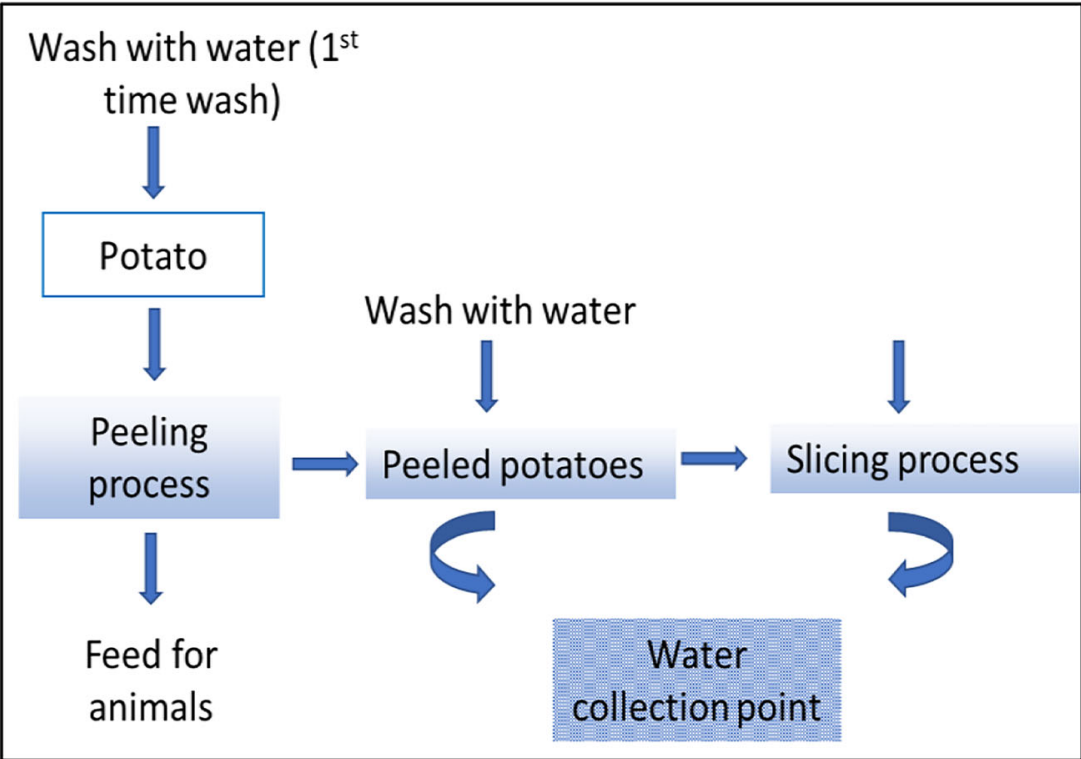

combinations of pre-treatments, such as centrifugation (with specifications; time $20 \mathrm{~min}$ at $8000 \mathrm{~g}$ and $20{ }^{\circ} \mathrm{C}$ ), sedimentation for $4 \mathrm{~h}$ followed by filtration using filter paper with specifications of 2.0, 2.5, and $0.22 \mu \mathrm{m}$ and PVDF/MF, have been used before applying the ultrafiltration process.

The strategic process with an explanation of the purposes for applying each pre-treatment and treatment step on wastewater is shown in Table 6. It was demonstrated that transmembrane pressure increases suddenly due to the phenomenon known as concentration polarization, and after that the feed was only pre-treated by centrifugation. After some time, there was no significant increase, but this may be due to the deposition of biopolymers, especially proteins, on the surface of the membrane. The increasing concentration of protein in the retentate of membrane filtration over time leads to the cake layer formation and pore blocking process. However, the pre- treatment of feed by centrifugation leading to microfiltration improved membrane performance concerning the fouling.

The recovery of protein using ultrafiltration along with the obtained concentration of the desired product was determined by applying an assay known as the BCA test. The initial calculated concentration of protein in the feed solution after applying centrifugation was $1.55 \pm 0.03 \mathrm{~g} / \mathrm{L}$. After applying a different pre-treatment process on the feed or wastewater, the amount of protein was determined in the obtained permeate of each process. The recovery percentage of protein was $72 \%$ by applying centrifugation to the feed solution, and this value fell to $62 \%$ after several pre-treatment applications (Table 7). However, it is also clear from Table 5 that the concentration of protein is increased in the retentate of the experiment including centrifugation, followed by MF with filter paper with a specification of $2.5 \mu \mathrm{m}$ for $20 \mathrm{~h}$.
Fig. 2 The composition of potato process wastewater (Mishra and Arora 2004; Guo et al. 2018)

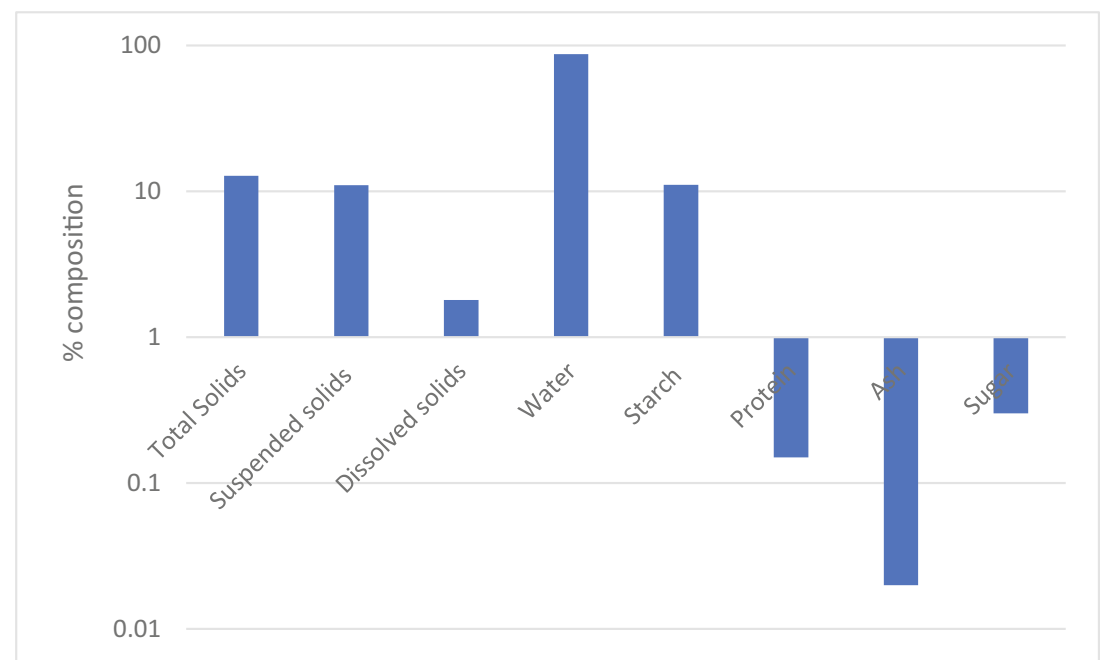


Table 6 Schematic representation of pre-treatment of PPW to reach the existing separation efficiency (Rajewska and Janiszewska 2017)

\begin{tabular}{ll}
$\begin{array}{l}\text { The waste stream from the potato processing industry } \\
\text { Pre-treatment techniques }\end{array}$ & Effects of pre-treatment \\
\hline Effect of centrifugation & $\begin{array}{c}\text { Efficient for removing large particles such as starch and fibres } \\
\text { from wastewater } \\
\text { Effective removal of insoluble and soluble starch and fibre } \\
\text { from wastewater }\end{array}$ \\
$\begin{array}{ll}\text { Filtration by the paper filter } \\
\text { (pore size } 2.5 \mu \mathrm{m})\end{array}$ \\
$\begin{array}{l}\text { Filtration } 0.22 \mu \mathrm{m} \text { PVDF microfiltration } \\
\text { Ultrafiltration by polysulfone membrane }\end{array}$ & $\begin{array}{l}\text { The retentate of membrane filtration is rich in the desired protein } \\
\text { The }\end{array}$
\end{tabular}

In each stage of the process, SDS-Page was applied to understand protein bands with dissimilar molecular weights. The results confirmed from the obtained bands of proteins with bigger molecular weight constitute the desired potato protein (patatin family), and other proteins remain intact during the sequence of several treatment stages (Li et al. 2019b). The obtained proteins remained intact from the denaturation process and no separate band was observable in the permeate of the UF membrane (Rajewska and Janiszewska 2017). The concentration of protein in each experiment was determined by examining the filtrate of filter paper of $2.5 \mu \mathrm{m}$ (MF feed), permeate of MF and permeate of UF using the LC-OCD technique (Miedzianka et al. 2012).

The total DOC present in the feed of the MF membrane was $2306.21 \mathrm{mg} / \mathrm{L}$ with $6 \%$ of DOC containing biopolymers, therefore amounting to about $142.05 \mathrm{mg} / \mathrm{L}$. After MF filtration, contents such as DOC and biopolymers in the permeate of MF that would be the feed for ultrafiltration were reduced to 1988.51 and $104.39 \mathrm{mg} / \mathrm{L}$, respectively $(5.25 \%$ of the dissolved organic carbon was biopolymers). The amount of protein is $100 \%$ in the feed of the ultrafiltration membrane. After filtration, the concentration of protein present in the UF permeate was negligible, which indicates that approximately all the protein present in the feed of UF revealed by LC-OCD was removed in the retentate. It was concluded from the work done by the researcher that the desired protein from the PPW can be accumulated up to 3.5 times that of its initial concentration using an efficient membrane. The polyethersulfone UF membrane with an MWCO of $10 \mathrm{kDa}$ was proven to be efficient in concentrating the protein from potato waste streams (Dabestani et al. 2017). However, loss of protein was unavoidable when multiple pre-treatments were conducted. To avoid the fouling mechanism of the membrane, several pretreatments were applied, such as the addition of chemicals (acid or basic) to lessen the denaturation of the desired protein. Membrane technology for protein recovery from potato wastewater has proven to be efficient, but it is still important that the value of the obtained protein in terms of its quality and purity be understood. Furthermore, it is also desirable to study the effect and concentration of total glycoalkaloids (TGA), a natural toxin already existing in potato and potato harvests, and attention should be paid to regulating the accumulation of this toxin in the obtained protein to evaluate the quality of the final product for future applications.

\section{Protein recovery from wastewater of the poultry processing industry by membrane technology}

With the rapid increase in the human population, there has been an immense rise in meat intake. The daily consumption of poultry (especially chicken) is growing at an even higher rate than that of other popular meats such as beef or pork (Castro-Muñoz and Ruby-Figueroa 2019). In this current situation, the waste streams from the poultry industry such as carcass debris and body fluids, mainly blood, are the main impurities, along with fat. Blood and debris are rich in proteins. Wastewaters from poultry have a higher biological and chemical oxygen demand than normal sewage waste streams
Table 7 Protein rejection by ultrafiltration membrane is calculated based on the bicinchoninic acid assay (BCA assay) (Xu et al. 2016; Li et al. 2020)

\begin{tabular}{lll}
\hline No. of Experiments & Protein recovery $(\%)$ & Concentration factor (CF) \\
\hline Centrifugation & 72 & 2.2 \\
Sedimentation (Sed.)/cent. & 70 & 2.2 \\
Centrifugation/microfiltration (MF) & 67 & 1.9 \\
Centrifugation/filter paper $20 \mu \mathrm{m}$ & 63 & 1.8 \\
Centrifugation/filter paper $2.5 \mu \mathrm{m}$ & 57 & 2.1 \\
Filter paper $2.5 \mu \mathrm{m} / \mathrm{MF}$ & $\mathrm{N} / \mathrm{A}$ & $\mathrm{N} / \mathrm{A}$ \\
Centrifugation/filter paper $2.5 \mu \mathrm{m} / \mathrm{MF}$ & 62 & 2.3 \\
Cent./filter paper $2.5 \mu \mathrm{m} / \mathrm{MF}$ (long-term $20 \mathrm{~h})$ & 62 & 3.5 \\
\hline
\end{tabular}


because of the high concentration of proteins. A method was proposed to restore valuable protein from poultry-handling industry waste streams by applying membrane technology such as the ultrafiltration process. In their study, researchers explored the possibility of retrieving protein from poultry wastewater via UF with an MWCO of around 30,000 kDa along with the development of parameters for the effective performance of the total process (Lo et al. 2005). In this perspective, if the ideal process circumstances are recognized, it is extremely relevant that UF can function at peak flux in the desired period, thus refuting the contrary results produced by the contaminated membrane (Le Roux and Belyea 1999).

It is well-known that UF has been extensively applied to the separation, concentration, and refinement of colloidal and higher molecular weight constituents present in solutions (Lo et al. 1997). Most fats in poultry streams were removed from wastewater through the implementation of different primary pre-treatments, including dissolved air flotation (DAF), and the placement of a UF unit right after the physical treatment of wastewater could greatly decrease membrane fouling. There is a need to study the methods to recover membrane performance by applying some special cleaning procedures to make this process effective for cost and durability. There is also a need to minimize the concentration of nutrients in the effluent for downstream processing (separation, concentration, and purification) to maintain the expected quality and functionality of the desired protein. The non-thermal UF process keeps protein denaturation from suffering during thermal procedures.

A diagrammatic presentation of procedures using a polysulfone UF membrane with a molecular weight cut-off of 30,000 Da is shown in Fig. 3 for the recovery of the desired protein from the poultry processing wastewater in the retentate after the membrane process. The wastewater undergoes the pretreatment to remove the fats and other components before passing this water from the membranes (to avoid membrane clogging). The polymer membrane, especially one made of polysulfone, is a commonly used UF membrane in the food sector. The polysulfone membrane has been recognized as having the least fouling drifts when treating skimmed milk (Kumar et al. 2013).

A flat-sheet compartment with a membrane with a specific area of $30 \mathrm{~cm}^{2}$ was used for the process assessment. The total fat in the waste samples was observed through the partitiongravimetric (PG) method (EPA Methods $5520 \mathrm{~B}$ ).

A distinctive flux report and variation in protein concentration through the membrane process are shown in Table 8 above. It can be predicted from the table that rapid flux decline takes place within just $20 \mathrm{~min}$ of filtration and continues to decrease throughout the process. Along with a decrease in the flux of the membrane over time, the protein content increased from 80 to $273 \mathrm{mg} / \mathrm{L}$ (Lo et al. 1997).

UF treatment can decrease the COD in the main waste stream by $58.86 \%$ (Lo et al. 2005). A negligible amount of protein was found in the permeate of the membrane. Residual COD in the permeate was normally documented with a safe direct discharge value $(200 \mathrm{mg} / \mathrm{L})$. This high COD value of permeate is due to the use of chemicals such as cleaners, antiseptics and flocculants throughout the processing, especially in pre-treatment, and there is possibly residual waste which causes a high COD value. The results obtained are in keeping with a prior report that elaborated on the UF process for the removal of sericin from wastewater from the silk degumming industry (Fabiani et al. 1996). The procedure produced permeate with high COD $(800 \mathrm{mg} / \mathrm{L})$. To overcome this high value, reverse osmosis was used, after which the COD value fell as low as $50 \mathrm{mg} / \mathrm{L}$. Consequently, after ultrafiltration, the ecological effects of final discharge need to be assessed in greater detail before it can be emitted into rivers and oceans, for example.

It was shown by (Martínez et al. 2000) that $\mathrm{pH}$ is a highly significant factor and has an obvious influence on the

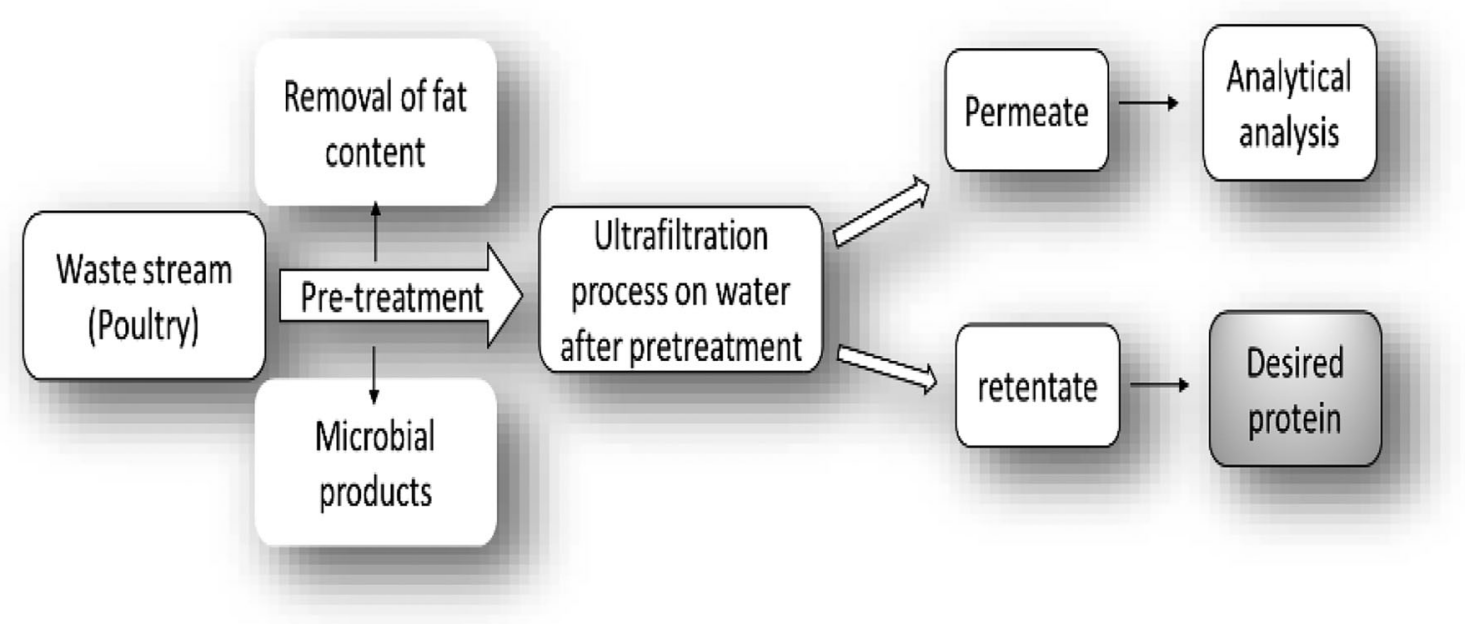

Fig. 3 Ultrafiltration membrane process for recovery of desired protein from poultry processing wastewater (Lo et al. 2005) 
Table 8 Changes in the flux of the membrane along with the concentration of desired protein during the ultrafiltration of poultry wastewater at specified parameters $25^{\circ} \mathrm{C} ; \mathrm{pH}$ (neutral); transmembrane pressure of 14 psi (Kumar et al. 2013)

\begin{tabular}{lll}
\hline Time $($ mins $)$ & Membrane flux $\left(\mathrm{Lm}^{-2} / \mathrm{h}\right)$ & Protein contents $(\mathrm{mg} / \mathrm{L})$ \\
\hline 0 & 264 & 80 \\
20 & 140 & $\sim 90$ \\
40 & $\sim 138$ & 100 \\
60 & 130 & $\sim 150$ \\
80 & $\sim 128$ & 200 \\
100 & 125 & 273 \\
\hline
\end{tabular}

configuration of protein molecules. The properties, including the electrical interaction of protein molecules, play a significant part in defining their interfaces with the surface of the membrane. Hence, for additional evaluation related to the outcome of $\mathrm{pH}$ on the membrane filtration process, an isoelectric point (pI) of protein removed from the waste stream (poultry) was investigated using the fractionation method (Fig. 4). It is vital to consider the optimum $\mathrm{pH}$ value of the solution and isoelectric point, which can prevent the formation of the cluster due to agglomeration (Honda et al. 1993; Guinee et al. 1997).

The isoelectric point of protein present in the waste stream was located at around pH 4.6 (Fig. 4). The isoelectric point of the desired protein was at $\mathrm{pH} 4.6$, which is far from the optimum $\mathrm{pH}$ value of 6.74 (Lo et al. 2005). pH 6.74 is favourable for the ultrafiltration of poultry wastewater, as that $\mathrm{pH}$ is effective for the prevention of protein coagulation that could cause adverse fouling and affect the overall membrane process. Even though extreme membrane fouling was still unavoidable after pre-treatment, back-flushing, or sampling flushing of the fouled membrane with chemical cleaning, was efficient in regaining the working performance of the membrane. An integrated approach to recovering protein from the poultry waste stream, including microfiltration, ultrafiltration, and vacuum membrane distillation, was studied (Honda et al. 1993).

The researcher tried to restore the desired protein in water according to the filtration sequence already used with membranes with an MWCO between 3 and $30 \mathrm{kDa}$. The membrane that was chosen for the next step is based on the removal of the COD value along with the protein retention capacity in the retentate. The integrated membrane process, including MF, UF, and vacuum membrane distillation (VMD), was used to purify water and protein.

In the case of the last stated procedures, practically all the protein obtained in the feed that is the permeate of the ultrafiltration process can be restored in the retentate. The solution proposed, using an integrated process, allows an almost ninefold decrease in the capacity of waste produced. This method also gave the outlook to use the recovered protein concentrate as a feed and for food production (Honda et al. 1993).

In the state-of-the-art work performed by (Lo et al. 2005), the concentration of the protein is about $40 \%$ of the total solids (TS) in the retentate. Direct evaporation could be helpful for the recovery of solids present in the concentrated final product. About $70 \%$ of the dry solid weight was recovered this way. By the application of the ultrafiltration process (polysulfone membrane) with an MWCO value of $30,000 \mathrm{Da}$, proteins from the poultry waste stream are concentrated in the final retentate, followed by a reduction in the total COD value applicable for discharge (Iwuoha and Umunnakwe 1997). It was proposed that, if other nutrient loads were reduced in the effluent undergoing downstream processing, one can avoid any impurity in the desired recovered protein and prevent the protein from harsh thermal degradation effects (Lo et al. 1997; Le Roux and Belyea 1999). Researchers also tried to recover protein by applying ultrafiltration on the solution obtained after mechanical extraction to
Fig. 4 Estimation of the isoelectric point of protein restored by fractionation method (Lo et al. 2005)

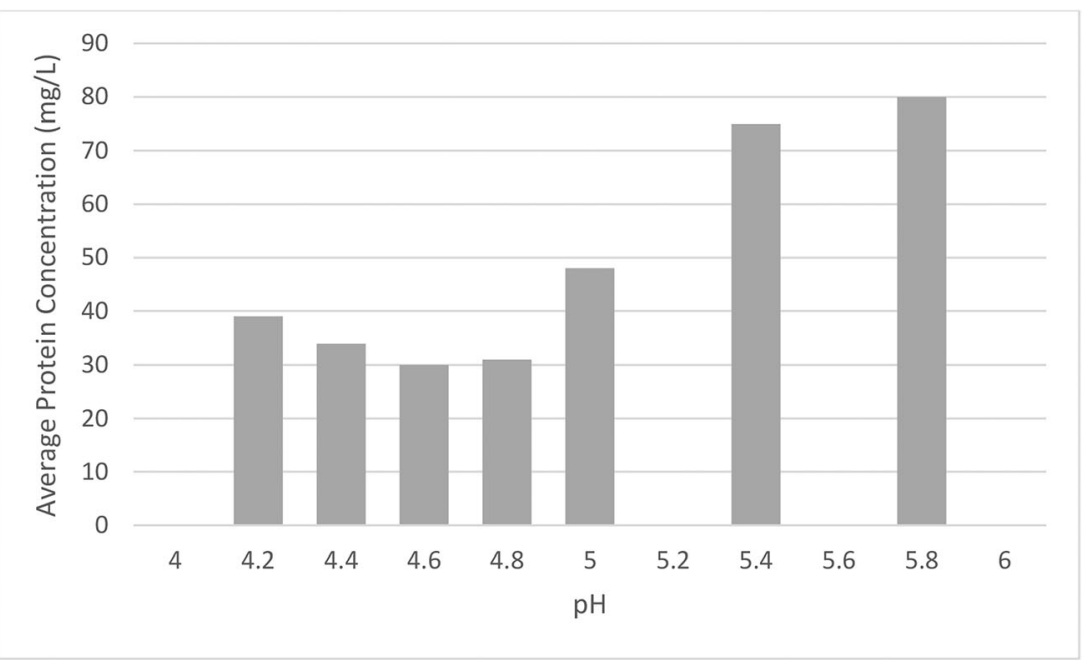


debone the turkey residue. The ultrafiltration on that solution was done without prominent fouling (clogging) of the membrane during the procedure.

\section{Protein recovery from alfalfa-processing wastewater using membrane technology}

Leaf protein obtained from alfalfa juice is a vital protein for animal feed and human food. Previously, the researcher recognized alfalfa juice as a competent source of good-quality leaf proteins. The main significant features of this protein are that they are abundant in nature with a high concentration of protein, valuable nutritional aspects and most importantly no animal cholesterol. Just like other food processing industries, the alfalfa processing industry produces plenty of wastewater. This wastewater is rich in protein, containing up to $50 \%$ of hydrophobic proteins. The wastewater contains diluted alfalfa juice along with cleaning detergents (Zhang et al. 2015b). Another researcher also recognized the wastewater of alfalfa as a source for nutrient renewal applicable to irrigation and restoring biomolecules (Lamsal et al. 2007; Xie et al. 2008).

Different separation systems were used for the removal of alfalfa proteins from diverse sources. The most commonly applied methods are chromatography (Ibarra-Herrera et al. 2011) fractionation by means of solvents (Koshchuh et al. 2004), heating (Bals and Dale 2011), crystallization (Firdaous et al. 2010), molecular sieve chromatography, centrifugation (Arulvasu et al. 2014), and ion exchange technology (Ibarra-Herrera et al. 2011). However, none of these methods provide good removal/separation efficiency for protein.

The ultrafiltration (UF) process shown in Fig. 5 can facilitate the downstream processing of protein present in alfalfa juice, whereas the concentration of the filtration process contains a protein that can be separated using precipitation for the production of feed for animals (Zhang et al. 2015a). It can also be effective for the production of renewable energy followed by anaerobic digestion (Venkata Mohan et al. 2008). There is also the possibility that permeate obtained after UF can undergo an additional filtration through a membrane of smaller pore size (nanofiltration or reverse osmosis), which results in drinking water (Sarkar et al. 2006), and the water can also be used to irrigate fields.

In the filtration process of alfalfa wastewater using the UF membrane, the filtration efficiency decreases over time because membrane fouling leads to an effect known as concentration polarization (Ma et al. 2017). If this effect continues, the efficiency of the membrane process faces a severe decline and results in increases in the overall procedure cost. To overcome this problem, a new investigation including a rotating disk membrane (RDM) unit was applied to lessen membrane fouling and recover flux performance. In the RDM process, the main phenomena that overcome the concentration polarization effect increase the shear rate (Zhang et al. 2014b).

To understand the recovery of protein along with the behaviour of membrane fouling during this process, (Zhang et al. 2014b) made efforts to accomplish a four-factor and three-level central combined response surface methodology (CCRSM) experimental plan to understand the collective operation parameters, including the significance of transmembrane pressure (TMP), feed flow rate, the effect of shear, and temperature. The ideal operation settings are likely to qualify the probable implementation of RDM for membrane wastewater behaviour in the future (Bensadallah et al. 2016).

Table 9 illustrates COD rejection, the removal efficiency of protein, and flux value of membranes, along with fouling, permeability recovery after membrane cleaning, and cost behaviour of processed UF membranes. The PES50 membrane showed the smallest removal of COD, rejection of protein, and maximum flux, probably due to the larger pore size distribution. However, the average diameter of protein present in the feed solution $(60-90 \mathrm{~nm})$ is bigger than that of the membrane PES50 having a pore size of $10 \mathrm{~nm}$. Therefore, according to the concept, most leaf proteins should be retained by the membrane (Zhang et al. 2015b).

\section{Protein recovery from the dairy waste stream using membranes}

Dairy wastewater is typified by severe $\mathrm{pH}$ changes and typically contains high concentrations of organic matter, solids and nutrients, as well as dissolved inorganic pollutants and traces of cleaning agents (de Souza Santana et al. 2016). In dairies, membrane-based technologies, and their combination with other methods such as biological, chemical and physical ones, are likely to be used for water recycling and resource harvesting (de Souza Santana et al. 2016).

The study performed by (Bortoluzzi et al. 2017) demonstrated that dairy wastewater handled by membrane-integrated processes can possibly meet the environmental disposal requirements of treated wastewater in the collection of water, as well as supporting the reuse of water in the dairy plant itself as well as in cooling and heating procedures. In the abovestated study, two stages of the integrated membrane filtration system have been used. The integration system uses the MF + $\mathrm{NF}$ process in one stage and the MF + RO system in other stages, using different operation parameters while treating the dairy processing waste stream. The results obtained from this study indicate the removal of suspended solids to a large extent using the MF membrane along with the reduction of turbidity and colour. The combination of the MF $+\mathrm{NF}$ process is more effective in the reduction of turbidity up to $96 \%$. Moreover, the complete reduction of turbidity (100\%) along with colour reduction (100\%) as well as TOC removal of $84 \%$ 


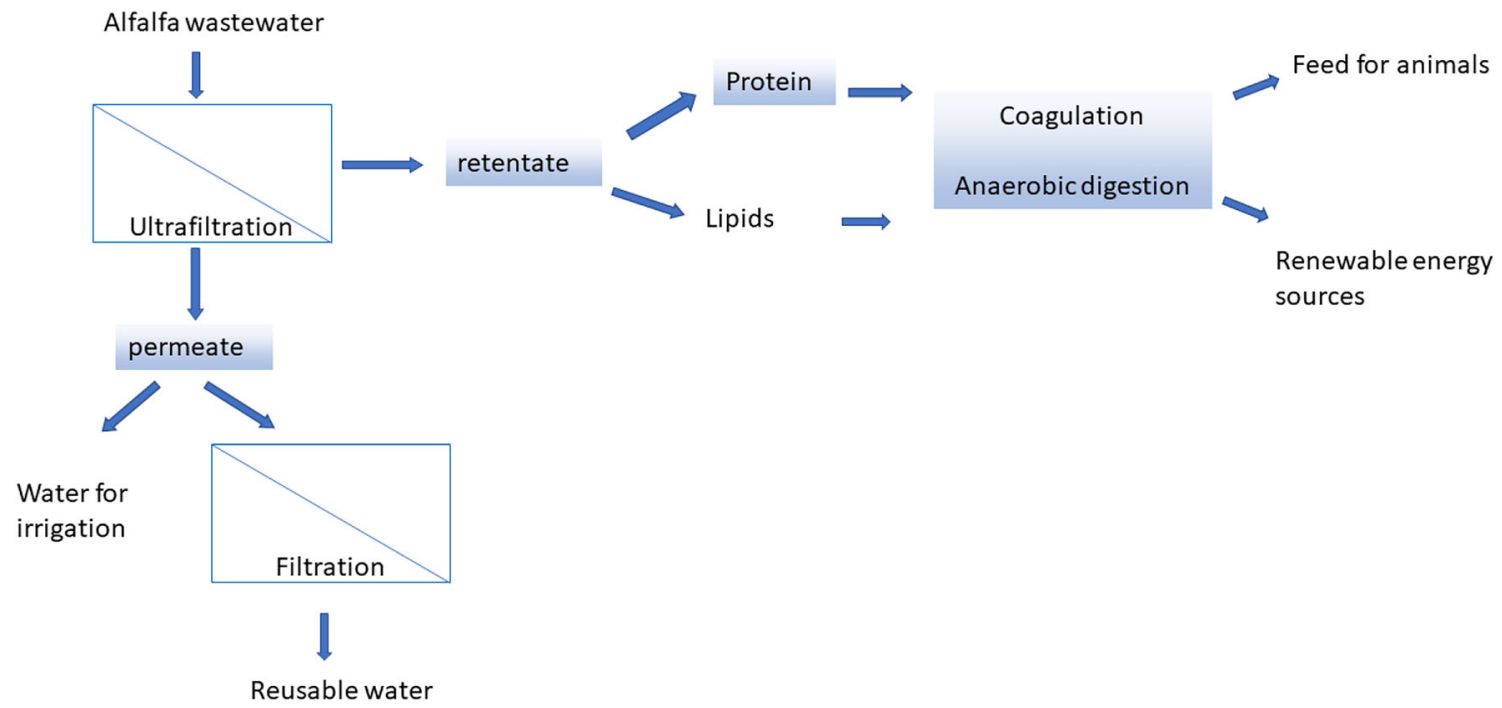

Fig. 5 Schematic representation of membrane process on the alfalfa waste stream and its applications (Zhang et al. 2015b; Gao et al. 2018)

was observed using the MF + RO integrating system (Bortoluzzi et al. 2017; Sert et al. 2017).

In state of the art, the use of UF membranes concerning their pore size and surface charge for the fractionation of the dairy components is accepted as a promising process especially in the valorisation of whey protein. However, due to the presence of a large number of proteins such as bovine serum albumin, $\breve{\alpha}$ - and $\beta$-lactoglobulin in the dairy wastewater can limit the use of the UF membrane, which contributes towards the severe membrane fouling (Barukčić et al. 2015; Brião et al. 2017). In a recent study (Damar et al. 2020), the whey protein recovery was investigated using different commercially available UF membranes with different characteristics. The membranes used in this study were regenerated cellulose acetate membrane, composite fluoropolymer membrane and polyethersulfone membrane. All the used membranes have the same cut-off of $10 \mathrm{kDa}$. The high roughness of the composite fluoropolymer membrane more likely increased the rejection of lactose and whey proteins in the retentate. The results indicated that the surface hydrophobicity of composite fluoropolymer and polyethersulfone membrane are considerably involved with the fouling resistance. Despite the low selectivity, the regenerated cellulose acetate membrane presented a better competence for the concentration of whey proteins due to its high antifouling content. Table 10 presents the membranes used for the recovery of proteins from different wastewaters and the limitation in their usage at a larger scale.

\section{Protein recovery from seafood processing wastewater}

Over the last decades, the importance of the shrimp industry to global economic development has been evident through shrimp exports and imports and the associated research performance. Wastewater produced in aquaculture needs an urgent management process to reduce its effects on the environment ( $\mathrm{Ng}$ et al. 2018). Research has recovered valuable

Table 9 The distinctive parameters of permeate for several membranes at a given temperature and pressure (Zhang et al. 2017, 2019)

\begin{tabular}{|c|c|c|c|c|c|c|c|c|c|}
\hline Used membrane & $\begin{array}{l}\text { Surface } \\
\text { material }\end{array}$ & $\begin{array}{l}\text { MWCO } \\
(\mathrm{kD})\end{array}$ & $\begin{array}{l}{ }^{1} \text { Water } \\
\text { permeability }\end{array}$ & $\begin{array}{l}\text { COD removal } \\
\text { efficiency } \%\end{array}$ & $\begin{array}{l}\text { Protein } \\
\text { removal \% }\end{array}$ & Fouling & ${ }^{4}$ Flux & $\begin{array}{l}\text { Recover } \\
\text { permeability } \%\end{array}$ & $\begin{array}{l}\text { Energy } \\
\text { cost } \\
\left(\mathrm{kWhm}^{-3}\right)\end{array}$ \\
\hline Polyethersulfone 20 & ${ }^{2} \mathrm{PES}$ & 20 & $>30-40$ & 31.52 & 72.92 & $\begin{array}{c}1.6051 \mathrm{E}+ \\
10\end{array}$ & 83.6 & 70.57 & 297.84 \\
\hline UH030P & ${ }^{3} \mathrm{PESH}$ & 30 & $40-50$ & 27.46 & 70.83 & $\begin{array}{c}7.0617 \mathrm{E}+ \\
09\end{array}$ & 153.0 & 80.07 & 162.74 \\
\hline PES50 & PES & 50 & $>70$ & 25.42 & 66.67 & $\begin{array}{l}7.0639 \mathrm{E}+ \\
09\end{array}$ & 183.6 & 73.91 & 135.62 \\
\hline
\end{tabular}

\footnotetext{
${ }^{1}$ Water permeability $\left(\mathrm{L} \mathrm{m}^{-2} \mathrm{~h}^{-1} \mathrm{bar}^{-1}\right)$

${ }^{2}$ PES, polyethersulfone

${ }^{3} \mathrm{PESH}$, permanently hydrophilic polyethersulfone

${ }^{4}$ Flux $\left(\mathrm{L} /\left(\mathrm{m}^{2} \mathrm{~h}\right)\right)$
} 
Table 10 Membranes used for the recovery of protein from waste sources and their limitation of the application

\begin{tabular}{|c|c|c|c|c|}
\hline No. & Waste source of protein & Membrane specification & Limitations & Reference \\
\hline 1 & $\begin{array}{l}\text { Yellow fin tuna (Thunnus } \\
\text { albacores) viscera }\end{array}$ & $\begin{array}{l}\text { UF-regenerated cellulose }(\mathrm{RC}) \\
\text { membranes ( } 76 \mathrm{~mm} \text { in diam- } \\
\text { eter) }\end{array}$ & $\begin{array}{l}\text { Membrane fouling with higher molecular } \\
\text { weight compounds }\end{array}$ & (Pezeshk et al. 2019) \\
\hline 2 & $\begin{array}{r}\text { Anti-scorpion serum } \\
\text { production wastes }\end{array}$ & $\begin{array}{l}\mathrm{UF}(10 \mathrm{kDa}) \text { and electrodialysis } \\
\text { process }\end{array}$ & $\begin{array}{l}\text { Multiple rinsing of the membrane was } \\
\text { essential }\end{array}$ & $\begin{array}{l}\text { (Bensadallah et al. 2016; } \\
\text { Castro-Muñoz and } \\
\text { Ruby-Figueroa 2019) }\end{array}$ \\
\hline 3 & $\begin{array}{l}\text { Tuna processing } \\
\text { by-products }\end{array}$ & $\begin{array}{l}\text { Cascade integrating UF (n.r.) and } \\
\text { NF (n.r.) membranes }\end{array}$ & $\begin{array}{l}\text { Membrane clogging due to the high protein } \\
\text { contents }\end{array}$ & (Klomklao and Benjakul 2017) \\
\hline 4 & $\begin{array}{l}\text { Tilapia by-product protein } \\
\text { hydrolysate }(\mathrm{TBH}) \text { sepa- } \\
\text { ration }\end{array}$ & $\begin{array}{l}\text { Flat-sheet RC with MWCO of } 10 \\
\text { and } 5 \mathrm{kDa}\end{array}$ & n.r. & (Roslan et al. 2017) \\
\hline 5 & $\begin{array}{l}\text { Dairy waste in the form of } \\
\text { whey proteins }\end{array}$ & $\begin{array}{l}\text { UF }(10 \mathrm{kDa}) . \text { membrane pore } \\
\text { size } 200-250 \mathrm{~nm}\end{array}$ & $\begin{array}{l}\text { Whey protein (b-lactoglobulin) aggregation } \\
\text { leads to severe fouling }\end{array}$ & $\begin{array}{l}\text { (Steinhauer et al. 2015; Ganju } \\
\text { and Gogate 2017) }\end{array}$ \\
\hline 6 & $\begin{array}{l}\text { Whey, a by-product of } \\
\text { cheese }\end{array}$ & $\begin{array}{l}\text { Flat-sheet membrane } \\
\quad\left(0.0061 \mathrm{~m}^{2}\right) \text { and a spiral } \\
\text { membrane }\left(0.22 \mathrm{~m}^{2}\right)\end{array}$ & $\begin{array}{l}\text { Aggregation of b-lactoglobulin protein takes } \\
\text { place as membrane shows retention of this } \\
\text { moiety }\end{array}$ & $\begin{array}{l}\text { (Baldasso et al. 2011; Argenta } \\
\text { and Scheer 2020) }\end{array}$ \\
\hline
\end{tabular}

n.r. not reported

components such as proteins from the shrimp wastewater using several methods. In a recent study, the protein-rich biomass from shrimp boiling water (SBW) was treated with different flocculants at different $\mathrm{pHs}$ to recover protein using flocculation and sedimentation techniques. The results obtained during this study indicated a maximum sedimentation of up to $80 \%$ of proteins from the biomass at $\mathrm{pH} 4$ (Forghani et al. 2020). In another case study, tuna processing industrial wastewater has been subjected to hydrolysis for the purpose of protein recovery using the fractionation process by the UF and NF membrane cascade in a continuous industrial-scale process. The proposed model was applied for the investigation of the most suitable configuration of UF and NF membranes in linear or dual cascades to obtain the maximum recovery of protein from the wastewater (Abejón et al. 2018).

The increase in the consumption of fish because of its high protein content and other nutritious values, especially tuna, leads to an increase in the wastewater produced during the processing in the industry. Several studies are being conducted on the recovery and separation of valuable components from the wastewater coming from the fish processing industry. The work performed includes the valorisation of tuna processing waste biomass for the recovery of valuable proteins and peptides with the integration of enzymatic hydrolysis and the membrane fractionation process (Saidi and Ben Amar 2016). The applied method in this study is important for producing valuable bioactive products from the tuna fish processing wastewater and in lowering the organic content of the wastewater generated from the food processing industry. In this study, the enzymatic hydrolysis coupled with the UF and NF membrane system leads to the biotransformation of protein present in the tuna processing industry wastewater to tuna protein hydrolysate. The obtained results from the evaluation of the amino acid composition and antioxidant study of the recovered protein show the presence of many valuable amino acids (aspartic acid, glycine, alanine, valine and leucine) in the extracted protein (Sayari et al. 2016). All these amino acids are found in the retentate of the NF membrane after membrane fractionation.

\section{Protein recovery and membrane fouling}

Membrane fouling is identified as the irreversible deposition of sediments on the active surface of a membrane, resulting in flux decline during the process and a loss of active operation. This is a problem during the filtration of high organic content wastewater such as industrial water, brackish water, and seawater (Penña et al. 2013; Castro-Muñoz et al. 2019). One of the main obstacles to applying membranes for protein recovery from the targeted wastewater is membrane fouling due to the concentration polarization effect (Castro-Muñoz et al. 2019). The term concentration polarization can be defined as the reversible fouling process, thus reducing the flux and permeability through the membrane (Bhattacharjee et al. 2017). There is also another phenomenon called pore blocking that also occurs during the recovery of proteins and is defined as an irreversible process; the pore blocking also leads to consequences such as flux decline during the membrane filtration process (Bhattacharjee et al. 2017; Issaoui and Limousy 2019). When studying the recovery of protein from high organic content waste streams using MF and NF membranes, the major drawback that results in reduced flux is the concentration polarization effect and pore blocking with cake layer formation on the surface of the membrane over time (Park et al. 2017; Aghapour Aktij et al. 2020). 
The filtration of high organic content wastewater through membranes is prone to fouling, and that leads to a significant increase to the cost with regard to the industrial-scale process. Consequently, there is a vital need for the potential cleaning procedure to minimize the membrane fouling for the efficient process and durability of membranes (Humpert et al. 2016). One of the most effective and useful solutions includes the backflushing and rinsing of the membrane after and during the procedure, and the other is chemical cleaning of the membrane after each process (Wallberg et al. 2003; Bogati et al. 2015). In order to reduce the membrane fouling during the process the membranes were rinsed with the permeate of the filtration process, as the permeate possesses the same $\mathrm{pH}$ as the original solution. Also, it is more likely that most of the pollutants that stick on the surface of the membrane were soluble to the permeate (Beyer et al. 2017). The other method used for the sustainable operation of the membrane process is chemical cleaning of both UF and NF membranes, using different chemical agents such as sodium hypochlorite $(\mathrm{NaClO})$ (Li et al. 2019a), which is effective for membrane fouling via organic wastewater treatment and microbial fouling (Malczewska and Żak 2019). Table 11 presents the cost analysis of protein recovery using membrane technology from different waste streams.

Most of the membrane process plants designed for the purification of wastewater from several sources utilize repeated cleaning of the membranes and their modules, using a range of chemicals to reestablish the membrane performance to the same level as before fouling. As mentioned in Table 11, the chemical cleaning of the membranes has some characteristic drawbacks, and one of the biggest is reducing the costeffectiveness of the overall process and putting an extra burden on the atmosphere. Hence, it is now time to thoroughly research the innovation of new strategies to overcome traditional remedies. For future studies, the researcher should focus, practice, and prioritize the more mechanical cleaning procedures, such as, e.g. the backflushing of the membrane during and after the procedure, rather than the traditional chemical cleaning method (Bogler et al. 2017; Matin et al. 2019; Nunes et al. 2020).

The recovery of protein from wastewater using several techniques, including membrane technology, will always remain an interesting topic for researchers and scientists all over the world. New advances day by day concerning new membrane materials and the integration of membranes with other processes is a matter of interest when the protein recovery is involved. However, we should explore the proper functional and environmental benchmarks for membranetechnology-assisted protein recovery from a variety of waste streams to overcome the hindrance that lies within the transfer of this process from laboratory-scale studies to the profitable market (Shahid et al. 2020; Xiao and Zhou 2020).

\section{Conclusion}

As discussed, there are several pathways towards the promising recovery of proteins from different waste sources. A variety of wastewaters have been investigated for the efficient recovery of protein using different techniques in the state of the art. It was demonstrated that purple photosynthetic bacteria along with microalgae are the most efficient and dominant mediators for the removal of organic substances and nutrients from red meat, pork- and poultry-processing wastewaters. Microbial protein is proven to be a worthwhile and available protein supply to satisfy the need for human as well as animal diet stability. A simple one-step treatment using bacteria provides both benefits, including the supply of protein sources and treatment of high-COD non-toxic organic wastewater. The process of protein recovery by bacteria can fulfil the requirement to release wastewater streams without any treatment. The obtained bacteria cells contain high concentrations of valuable molecules including proteins, polysaccharides, carotenoids, bacteriochlorophyll and coenzyme Q10. However, there are some drawbacks to this process, including the existence of many nucleic acids in some entities, which makes its utilization by human beings unsuitable, and these molecules should be handled properly and within the limit range. Moreover, post-treatment of the obtained single-cell protein is also significant because of its susceptibility to any impurities. In the coming years, it has been predicted that microorganisms will be an important source of food additives due to their efficiency in manufacturing high-quality protein from waste substances.

Table 11 Cost analysis of different wastewater treated using membranes

\begin{tabular}{|c|c|c|c|c|}
\hline No. & Wastewater & Operational cost & Treatment method & Reference \\
\hline 1 & $\begin{array}{l}\text { Dairy waste stream } \\
\text { (milk protein) }\end{array}$ & 64-3374 US\$/cubic metre of treated effluent & $\begin{array}{l}\text { Oxygen injection into the physicochemical } \\
\text { treatment system }\end{array}$ & (Martín-Rilo et al. 2015) \\
\hline 2 & $\begin{array}{l}\text { Microalgae biomass } \\
\quad \text { (extraction of protein) }\end{array}$ & $0.12 \mathrm{US} \$ / \mathrm{kg}$ of microalgae sample & Polyethersulfone membrane & (Lorente et al. 2018) \\
\hline 3 & Whey protein & US $\$ 436,000$ & UF/RO process & (Wen-qiong et al. 2019) \\
\hline 4 & Milk protein & US $\$ 322,882.40$ (annual cost) & RO operating system & (Brião et al. 2019) \\
\hline
\end{tabular}


However, to cover the future need for protein and achieve self-sufficiency, there is still a gap to developing new technologies for large-scale manufacturing that needs to be overcome. The implementation of membrane technology for protein recovery has also been proven to work effectively. Also, the integration of MF, UF, and VMD can allow a reduction in the volume of waste generated that is almost nine times greater and can establish an option to make a protein concentrate suitable for human and animal needs. The recovery of different types of proteins from wastewaters using membranes has been discussed in detail in this paper. The advantages associated with using membranes in the recovery of proteins along with other valuable products from the potato processing, dairy and seafood processing industries has been taken into special consideration in this study. Membrane fouling is always associated with the process of protein recovery. The backflushing of the membrane with available cleaning reagents was found to be proficient in improving the restoration ability of the membrane. The development of efficient technologies and improvement in traditionally available techniques of protein recovery from waste streams can provide high-quality protein and reduce the gap between the demand for and supply of proteins, making them available for humans and animals. However, there is still a need for more research to find new and more potential wastes as a protein source via the implementation of membranes for the sake of the long-term stability of our system.

Acknowledgments I would like to acknowledge Assoc. prof. Arto Pihlajamäki for his time to read this mini review.

Authors' contributions KS, VS, and MS provide a substantial contribution to the conception and design of this mini-review. $\mathrm{KS}$ is the major contributor of literature search and data analysis for this mini review.

$\mathrm{KS}$ analyzed and interpreted the data for this mini-review article. KS analyzed and interpreted the data for this mini-review article. KS is the major contributor in drafting this mini review. KS, VS, and MS contributed to critically revising the article for important intellectual content.

All the authors read and approved the final version of this mini-review and agree to approve for sending for publication in this esteemed journal.

Funding Open Access funding provided by LUT University (previously Lappeenranta University of Technology (LUT)). The authors acknowledge the funding from Maa- ja vesitekniikan tuki ry (MVTT foundation).

Data availability Not applicable.

\section{Compliance with ethical standards}

Ethics approval and consent to participate Not applicable.

\section{Consent for publication Not applicable.}

Competing interests The authors declare that they have no competing interests.
Open Access This article is licensed under a Creative Commons Attribution 4.0 International License, which permits use, sharing, adaptation, distribution and reproduction in any medium or format, as long as you give appropriate credit to the original author(s) and the source, provide a link to the Creative Commons licence, and indicate if changes were made. The images or other third party material in this article are included in the article's Creative Commons licence, unless indicated otherwise in a credit line to the material. If material is not included in the article's Creative Commons licence and your intended use is not permitted by statutory regulation or exceeds the permitted use, you will need to obtain permission directly from the copyright holder. To view a copy of this licence, visit http://creativecommons.org/licenses/by/4.0/.

\section{References}

Abejón R, Belleville MP, Sanchez-Marcano J, Garea A, Irabien A (2018) Optimal design of industrial scale continuous process for fractionation by membrane technologies of protein hydrolysate derived from fish wastes. Sep Purif Technol 197:137-146. https://doi.org/ 10.1016/j.seppur.2017.12.057

Aghapour Aktij S, Zirehpour A, Mollahosseini A, Taherzadeh MJ, Tiraferri A, Rahimpour A (2020) Feasibility of membrane processes for the recovery and purification of bio-based volatile fatty acids: a comprehensive review. J Ind Eng Chem 81:24-40. https://doi.org/ 10.1016/j.jiec.2019.09.009

Álvarez C, Rendueles M, Díaz M (2012) Production of porcine hemoglobin peptides at moderate temperature and medium pressure under a nitrogen stream. Functional and antioxidant properties. J Agric Food Chem 60:5636-5643. https://doi.org/10.1021/jf300400k

Anupama RP (2000) Value-added food: single cell protein. Biotechnol Adv 18:459-479. https://doi.org/10.1016/S0734-9750(00)00045-8

Argenta AB, Scheer ADP (2020) Membrane separation processes applied to whey: a review. Food Rev Int 36:499-528. https://doi.org/10. 1080/87559129.2019.1649694

Arulvasu C, Shakthi SKS, Babu G, Radhakrishnan N (2014) Purification and identification of bioactive protein from leaves of Datura inoxia P.mil. Biomed Prev Nutr 4:143-149. https://doi.org/10.1016/j. bionut.2013.12.002

Azad SA, Vikineswary S, Chong VC, Ramachandran KB (2004) Rhodovulum sulfidophilum in the treatment and utilization of sardine processing wastewater. Lett Appl Microbiol 38:13-18. https:// doi.org/10.1046/j.1472-765X.2003.01435.x

Baldasso C, Kanan JHC, Tessaro IC (2011) An investigation of the fractionation of whey proteins by two microfiltration membranes with nominal pore size of $0.1 \mu \mathrm{m}$. Int J Dairy Technol 64:343-349. https://doi.org/10.1111/j.1471-0307.2011.00693.x

Bals B, Dale BE (2011) Economic comparison of multiple techniques for recovering leaf protein in biomass processing. Biotechnol Bioeng 108:530-537. https://doi.org/10.1002/bit.22973

Barukčić I, Božanić R, Kulozik U (2015) Influence of process temperature and microfiltration pre-treatment on flux and fouling intensity during cross-flow ultrafiltration of sweet whey using ceramic membranes. Int Dairy J 51:1-7. https://doi.org/10.1016/j.idairyj.2015.07. 002

Batstone DJ, Hülsen T, Mehta CM, Keller J (2015) Platforms for energy and nutrient recovery from domestic wastewater: a review. Chemosphere 140:2-11. https://doi.org/10.1016/j.chemosphere. 2014.10.021

Beena MS, Chandy T, Sharma CP (1994) Phenyl alanine, tryptophan immobilized chitosan beads as adsorbents for selective removal of immunoproteins. J Biomater Appl 8:385-403. https://doi.org/10. $1177 / 088532829400800405$ 
Bensadallah L, Grib H, Abdi N, Drouiche N, Mameri N (2016) Valorization of by-products resulting from the anti scorpion serum production wastes using membrane techniques. J Ind Eng Chem 41: 75-81. https://doi.org/10.1016/j.jiec.2016.07.007

Beyer F, Laurinonyte J, Zwijnenburg A, Stams AJM, Plugge CM (2017) Membrane fouling and chemical cleaning in three full-scale reverse osmosis plants producing demineralized. Water J Eng (United Kingdom) 2017:2017-2014. https://doi.org/10.1155/2017/6356751

Bhattacharjee C, Saxena VK, Dutta S (2017) Fruit juice processing using membrane technology: a review. Innov Food Sci Emerg Technol 43:136-153. https://doi.org/10.1016/j.ifset.2017.08.002

Bogati R, Goodwin C, Marshall K, Leung KT, Liao BQ (2015) Optimization of chemical cleaning for improvement of membrane performance and fouling control in drinking water treatment. Sep Sci Technol 50:1835-1845. https://doi.org/10.1080/01496395. 2015.1009116

Bogler A, Lin S, Bar-Zeev E (2017) Biofouling of membrane distillation, forward osmosis and pressure retarded osmosis: principles, impacts and future directions. J Membr Sci 542:378-398. https://doi.org/10. 1016/j.memsci.2017.08.001

Bortoluzzi AC, Faitão JA, Di Luccio M et al (2017) Dairy wastewater treatment using integrated membrane systems. J Environ Chem Eng 5:4819-4827. https://doi.org/10.1016/j.jece.2017.09.018

Brião VB, Seguenka B, Zanon CD, Milani A (2017) $<$ b $>$ Cake formation and the decreased performance of whey ultrafiltration. Acta Sci Technol 39:517. https://doi.org/10.4025/actascitechnol.v39i5. 27585

Brião VB, Vieira Salla AC, Miorando T, Hemkemeier M, Cadore Favaretto DP (2019) Water recovery from dairy rinse water by reverse osmosis: giving value to water and milk solids. Resour Conserv Recycl 140:313-323. https://doi.org/10.1016/j.resconrec. 2018.10.007

Cao K, Zhi R, Zhang G (2020) Photosynthetic bacteria wastewater treatment with the production of value-added products: a review. Bioresour Technol 299:299. https://doi.org/10.1016/j.biortech. 2019.122648

Castro-Muñoz R, Ruby-Figueroa R (2019) Membrane technology for the recovery of high-added value compounds from meat processing Coproducts. Sustain Meat Prod Process:127-143. https://doi.org/ 10.1016/b978-0-12-814874-7.00007-9

Castro-Muñoz R, Conidi C, Cassano A (2019) Membrane-based technologies for meeting the recovery of biologically active compounds from foods and their by-products. Crit Rev Food Sci Nutr 59: 2927-2948. https://doi.org/10.1080/10408398.2018.1478796

Chen Y, Jiang S, Yuan H, Zhou Q, Gu G (2007) Hydrolysis and acidification of waste activated sludge at different pHs. Water Res 41:683689. https://doi.org/10.1016/j.watres.2006.07.030

Chen J, Wei J, Ma C, Yang Z, Li Z, Yang X, Wang M, Zhang H, Hu J, Zhang C (2020) Photosynthetic bacteria-based technology is a potential alternative to meet sustainable wastewater treatment requirement? Environ Int 137:105417. https://doi.org/10.1016/j.envint. 2019.105417

Chong ASM, Zhao XS, Kustedjo AT, Qiao SZ (2004) Functionalization of large-pore mesoporous silicas with organosilanes by direct synthesis. Microporous Mesoporous Mater 72:33-42. https://doi.org/ 10.1016/j.micromeso.2004.04.015

Dabestani S, Arcot J, Chen V (2017) Protein recovery from potato processing water: pre-treatment and membrane fouling minimization. $\mathrm{J}$ Food Eng 195:85-96. https://doi.org/10.1016/j.jfoodeng.2016.09. 013

Damar I, Cinar K, Gulec HA (2020) Concentration of whey proteins by ultrafiltration: comparative evaluation of process effectiveness based on physicochemical properties of membranes. Int Dairy J 111: 104823. https://doi.org/10.1016/j.idairyj.2020.104823

Dang X, Yang M, Zhang B, Chen H, Wang Y (2019) Recovery and utilization of collagen protein powder extracted from chromium leather scrap waste. Environ Sci Pollut Res 26:7277-7283. https:// doi.org/10.1007/s11356-019-04226-x

Das B, Sarkar S, Sarkar A, Bhattacharjee S, Bhattacharjee C (2016) Recovery of whey proteins and lactose from dairy waste: a step towards green waste management. Process Saf Environ Prot 101: 27-33. https://doi.org/10.1016/j.psep.2015.05.006

de Souza Santana RS, Pretti AA, Moreno JG et al (2016) Effect of biomass configuration on the behavior of pilot-scale anaerobic batch reactors treating dairy wastewater. Int Biodeterior Biodegrad 106: 80-87. https://doi.org/10.1016/j.ibiod.2015.10.006

Deka JR, Saikia D, Lai YS, Tsai CH, Chang WC, Kao HM (2015) Roles of nanostructures and carboxylic acid functionalization of ordered cubic mesoporous silicas in lysozyme immobilization. Microporous Mesoporous Mater 213:150-160. https://doi.org/10.1016/j. micromeso.2015.04.015

Deng JJ, Mao HH, Fang W et al (2020) Enzymatic conversion and recovery of protein, chitin, and astaxanthin from shrimp shell waste. J Clean Prod 271:122655. https://doi.org/10.1016/j.jclepro.2020. 122655

Dikshit PK, Moholkar VS (2016) Optimization of 1,3-dihydroxyacetone production from crude glycerol by immobilized Gluconobacter oxydans MTCC 904. Bioresour Technol 216:1058-1065. https:// doi.org/10.1016/j.biortech.2016.01.100

Dotsenko G, Lange L (2017) Enzyme enhanced protein recovery from green biomass pulp. Waste Biomass Valoriz 8:1257-1264. https:// doi.org/10.1007/s12649-016-9718-7

Eding EH, Kamstra A, Verreth JAJ, Huisman EA, Klapwijk A (2006) Design and operation of nitrifying trickling filters in recirculating aquaculture: a review. Aquac Eng 34:234-260. https://doi.org/10. 1016/j.aquaeng.2005.09.007

Fabiani C, Pizzichini M, Spadoni M, Zeddita G (1996) Treatment of waste water from silk degumming processes for protein recovery and water reuse. Desalination 105:1-9. https://doi.org/10.1016/ 0011-9164(96)00050-1

Fiorentini R, Galoppini C (1983) The proteins from leaves. Qual Plant Plant Foods Hum Nutr 32:335-350. https://doi.org/10.1007/ BF01091193

Firdaous L, Dhulster P, Amiot J, Doyen A, Lutin F, Vézina LP, Bazinet L (2010) Investigation of the large-scale bioseparation of an antihypertensive peptide from alfalfa white protein hydrolysate by an electromembrane process. J Membr Sci 355:175-181. https://doi. org/10.1016/j.memsci.2010.03.018

Forghani B, Bordes R, Ström A, Undeland I (2020) Recovery of a protein-rich biomass from shrimp (Pandalus borealis) boiling water: a colloidal study. Food Chem 302:125299. https://doi.org/10.1016/j. foodchem.2019.125299

Fritsch C, Staebler A, Happel A, Cubero Márquez M, Aguiló-Aguayo I, Abadias M, Gallur M, Cigognini I, Montanari A, López M, SuárezEstrella F, Brunton N, Luengo E, Sisti L, Ferri M, Belotti G (2017) Processing, valorization and application of bio-waste derived compounds from potato, tomato, olive and cereals: a review. Sustain 9: 1-46. https://doi.org/10.3390/su9081492

Ganju S, Gogate PR (2017) A review on approaches for efficient recovery of whey proteins from dairy industry effluents. J Food Eng 215:84 96. https://doi.org/10.1016/j.jfoodeng.2017.07.021

Gao J, Qiu Y, Hou B, Zhang Q, Zhang X (2018) Treatment of wastewater containing nickel by complexation- ultrafiltration using sodium polyacrylate and the stability of PAA-Ni complex in the shear field. Chem Eng J 334:1878-1885. https://doi.org/10.1016/j.cej.2017.11. 087

Gascón V, Díaz I, Márquez-Álvarez C, Blanco RM (2014) Mesoporous silicas with tunable morphology for the immobilization of laccase. Molecules 19:7057-7071. https://doi.org/10.3390/ molecules 19067057

Getha K, Vikineswary S, Chong VC (1998) Isolation and growth of the phototrophic bacterium Rhodopseudomonas palustris strain B1 in 
sago-starch-processing wastewater. World J Microbiol Biotechnol 14:505-511. https://doi.org/10.1023/A:1008855125634

Ghosh S, Gillis A, Sheviryov J, Levkov K, Golberg A (2019) Towards waste meat biorefinery: extraction of proteins from waste chicken meat with non-thermal pulsed electric fields and mechanical pressing. J Clean Prod 208:220-231. https://doi.org/10.1016/j.jclepro. 2018.10.037

Gopinatha Kurup G, Adhikari B, Zisu B (2019) Recovery of proteins and lipids from dairy wastewater using food grade sodium lignosulphonate. Water Resour Ind 22:100114. https://doi.org/10. 1016/j.wri.2019.100114

Guest JS, Skerlos SJ, Barnard JL, Beck MB, Daigger GT, Hilger H, Jackson SJ, Karvazy K, Kelly L, Macpherson L, Mihelcic JR, Pramanik A, Raskin L, van Loosdrecht MCM, Yeh D, Love NG (2009) A new planning and design paradigm to achieve sustainable resource recovery from wastewater. Environ Sci Technol 43:61266130. https://doi.org/10.1021/es9010515

Guinee TP, Gorry CB, O'Callaghan DJ et al (1997) The effects of composition and some processing treatments on the rennet coagulation properties of milk. Int J Dairy Technol 50:99-106. https://doi.org/ 10.1111/j.1471-0307.1997.tb01747.x

Guo J, Liu J, Yang Y, Zhou Y, Jiang S, Chen C (2018) Fermentation and kinetics characteristics of a bioflocculant from potato starch wastewater and its application. Sci Rep 8:1-11. https://doi.org/10.1038/ s41598-018-21796-x

Han Y, Lee SS, Ying JY (2007) Spherical siliceous mesocellular foam particles for high-speed size exclusion chromatography. Chem Mater 19:2292-2298. https://doi.org/10.1021/cm063050x

Hao J, Wang X, Wang H (2017) Investigation of polyhydroxyalkanoates (PHAs) biosynthesis from mixed culture enriched by valeratedominant hydrolysate. Front Environ Sci Eng 11:1-11. https://doi. org/10.1007/s11783-017-0896-8

Hartmann M, Kostrov X (2013) Immobilization of enzymes on porous silicas - benefits and challenges. Chem Soc Rev 42:6277-6289. https://doi.org/10.1039/c3cs60021a

He Q, Shi J (2011) Mesoporous silica nanoparticle based nano drug delivery systems: synthesis, controlled drug release and delivery, pharmacokinetics and biocompatibility. J Mater Chem 21:58455855. https://doi.org/10.1039/c0jm03851b

Honda M, McDougall I, Patterson D (1993) Solar noble gases in the earth: the systematics of helium-neon isotopes in mantle derived samples. Lithos 30:257-265. https://doi.org/10.1007/s13762-0140557-4

Hülsen T, Batstone DJ, Keller J (2014) Phototrophic bacteria for nutrient recovery from domestic wastewater. Water Res 50:18-26. https:// doi.org/10.1016/j.watres.2013.10.051

Hülsen T, Hsieh K, Lu Y, Tait S, Batstone DJ (2018) Simultaneous treatment and single cell protein production from agri-industrial wastewaters using purple phototrophic bacteria or microalgae - a comparison. Bioresour Technol 254:214-223. https://doi.org/10. 1016/j.biortech.2018.01.032

Humpert D, Ebrahimi M, Czermak P (2016) Membrane technology for the recovery of lignin: a review. Membranes (Basel) 6:1-13. https:// doi.org/10.3390/membranes6030042

Ibarra-Herrera CC, Aguilar O, Rito-Palomares M (2011) Application of an aqueous two-phase systems strategy for the potential recovery of a recombinant protein from alfalfa (Medicago sativa). Sep Purif Technol 77:94-98. https://doi.org/10.1016/j.seppur.2010.11.025

Iftekhar S, Srivastava V, Sillanpää M (2017) Enrichment of lanthanides in aqueous system by cellulose based silica nanocomposite. Chem Eng J 320:151-159. https://doi.org/10.1016/j.cej.2017.03.051

Issaoui M, Limousy L (2019) Low-cost ceramic membranes: synthesis, classifications, and applications. C R Chim 22:175-187. https://doi. org/10.1016/j.crci.2018.09.014

Iwuoha CI, Umunnakwe KE (1997) Chemical, physical and sensory characteristics of soymilk as affected by processing method, temperature and duration of storage. Food Chem 59:373-379. https://doi.org/10.1016/S0308-8146(96)00250-6

Jayathilakan K, Sultana K, Radhakrishna K, Bawa AS (2012) Utilization of byproducts and waste materials from meat, poultry and fish processing industries: a review. J Food Sci Technol 49:278-293. https://doi.org/10.1007/s13197-011-0290-7

Johari K, Saman N, Mat H (2014) A comparative evaluation of mercury(II) adsorption equilibrium and kinetics onto silica gel and sulfur-functionalised silica gels adsorbents. Can J Chem Eng 92: 1048-1058. https://doi.org/10.1002/cjce.21949

Kaewsuk J, Thorasampan W, Thanuttamavong M, Seo GT (2010) Kinetic development and evaluation of membrane sequencing batch reactor (MSBR) with mixed cultures photosynthetic bacteria for dairy wastewater treatment. J Environ Manag 91:1161-1168. https://doi.org/10.1016/j.jenvman.2010.01.012

Kang K, Quitain AT, Daimon H, Noda R, Goto N, Hu HY, Fujie K (2001) Optimization of amino acids production from waste fish entrails by hydrolysis in sub- and supercritical water. Can J Chem Eng 79:65-70. https://doi.org/10.1002/cjce.5450790110

Kaspar AA, Reichert JM (2013) Future directions for peptide therapeutics development. Drug Discov Today 18:807-817. https://doi.org/10. 1016/j.drudis.2013.05.011

Khosravi-Darani K, Mokhtari Z-B, Amai T, Tanaka K (2013) Microbial production of poly(hydroxybutyrate) from $\mathrm{C} 1$ carbon sources. Appl Microbiol Biotechnol 97(4):1407-1424

Kim J, Lee J, Bin NH et al (2005) A magnetically separable, highly stable enzyme system based on nanocomposites of enzymes and magnetic nanoparticles shipped in hierarchically ordered, mesocellular, mesoporous silica. Small 1:1203-1207. https://doi.org/10.1002/smll. 200500245

Kinsella JE (1988) Ribulose bisphosphate carboxylase/oxygenase (rubisco) from green leaves - potential as a food protein. Food Rev Int 4:93-127. https://doi.org/10.1080/87559128809540823

Klomklao S, Benjakul S (2017) Utilization of tuna processing byproducts: protein hydrolysate from skipjack tuna (Katsuwonus pelamis) viscera. J Food Process Preserv 41. https://doi.org/10. $1111 /$ jfpp. 12970

Koshchuh W, Povoden G, Thang VH et al (2004) Production of leaf protein concentrate from ryegrass (Lolium perenne $\mathrm{x}$ multiflorum) and alfalfa (Medicago sativa subsp. sativa). Comparison between heat coagulation/centrifiguration and ultrafiltration. Desalination 163:253-259. https://doi.org/10.1016/S0011-9164(04)90197-X

Kumar P, Sharma N, Ranjan R, Kumar S, Bhat ZF, Jeong DK (2013) Perspective of membrane technology in dairy industry: a review. Asian Aust J Anim Sci 26:1347-1358. https://doi.org/10.5713/ ajas.2013.13082

Lamsal BP, Koegel RG, Gunasekaran S (2007) Some physicochemical and functional properties of alfalfa soluble leaf proteins. LWT Food Sci Technol 40:1520-1526. https://doi.org/10.1016/j.lwt.2006.11. 010

Le Roux LD, Belyea RL (1999) Effects of ultrafiltration membrane concentration and drying temperature on nutritional value of biosolids from a milk processing plant. Bioresour Technol 70:17-21. https:// doi.org/10.1016/S0960-8524(99)00023-1

Li K, Li S, Huang T, Dong C, Li J, Zhao B, Zhang S (2019a) Chemical cleaning of ultrafiltration membrane fouled by humic substances: comparison between hydrogen peroxide and sodium hypochlorite. Int J Environ Res Public Health 16:16. https://doi.org/10.3390/ ijerph16142568

Li Y, Zhang M, Zheng C, Hu L, Wang C, Jiang J, He B, Jiang G (2019b) Analysis of silver-associated proteins in pathogen via combination of native SDS-PAGE, fluorescent staining, and inductively coupled plasma mass spectrometry. J Chromatogr A 1607:460393. https:// doi.org/10.1016/j.chroma.2019.460393

Li H, Zeng X, Shi W, Zhang H, Huang S, Zhou R, Qin X (2020) Recovery and purification of potato proteins from potato starch 
wastewater by hollow fiber separation membrane integrated process. Innov Food Sci Emerg Technol 63:102380. https://doi.org/10.1016/ j.ifset.2020.102380

Lin CH, Deka JR, Wu CE, Tsai CH, Saikia D, Yang YC, Kao HM (2017) Bifunctional cage-type cubic mesoporous silica SBA-1 nanoparticles for selective adsorption of dyes. Chem Asian J 12:1314-1325. https://doi.org/10.1002/asia.201700286

Lo YM, Yang ST, Min DB (1997) Ultrafiltration of xanthan gum fermentation broth: process and economic analyses. J Food Eng 31: 219-236. https://doi.org/10.1016/S0260-8774(96)00068-4

Lo YM, Cao D, Argin-Soysal S, Wang J, Hahm TS (2005) Recovery of protein from poultry processing wastewater using membrane ultrafiltration. Bioresour Technol 96:687-698. https://doi.org/10.1016/j. biortech.2004.06.026

Løkra S, Helland MH, Claussen IC, Strætkvern KO, Egelandsdal B (2008) Chemical characterization and functional properties of a potato protein concentrate prepared by large-scale expanded bed adsorption chromatography. LWT Food Sci Technol 41:1089-1099. https://doi.org/10.1016/j.lwt.2007.07.006

Lorente E, Hapońska M, Clavero E, Torras C, Salvadó J (2018) Steam explosion and vibrating membrane filtration to improve the processing cost of microalgae cell disruption and fractionation. Processes 6. https://doi.org/10.3390/pr6040028

Ma W, Xu L, Li X, Shen S, Wu M, Bai Y, Liu H (2017) Cysteinefunctionalized metal-organic framework: facile synthesis and high efficient enrichment of $\mathrm{N}$-linked glycopeptides in cell lysate. ACS Appl Mater Interfaces 9:19562-19568. https://doi.org/10.1021/ acsami. $7 \mathrm{~b} 02853$

Malczewska B, Żak A (2019) Structural changes and operational deterioration of the Uf polyethersulfone (Pes) membrane due to chemical cleaning. Sci Rep 9:1-14. https://doi.org/10.1038/s41598-01836697-2

Marcet I, Álvarez C, Paredes B, Díaz M (2016) The use of sub-critical water hydrolysis for the recovery of peptides and free amino acids from food processing wastes. Review of sources and main parameters. Waste Manag 49:364-371. https://doi.org/10.1016/j.wasman. 2016.01.009

Maria Chong AS, Zhao XS (2004) Functionalized nanoporous silicas for the immobilization of penicillin acylase. Appl Surf Sci 237:398 404. https://doi.org/10.1016/j.apsusc.2004.06.080

Martínez F, Martín A, Prádanos P, Calvo JI, Palacio L, Hernández A (2000) Protein adsorption and deposition onto microfiltration membranes: the role of solute-solid interactions. J Colloid Interface Sci 221:254-261. https://doi.org/10.1006/jcis.1999.6575

Martín-Rilo S, Coimbra RN, Martín-Villacorta J, Otero M (2015) Treatment of dairy industry wastewater by oxygen injection: performance and outlay parameters from the full scale implementation. J Clean Prod 86:15-23. https://doi.org/10.1016/j.jclepro.2014.08.026

Masuda Y, Kugimiya SI, Kawachi Y, Kato K (2014) Interparticle mesoporous silica as an effective support for enzyme immobilisation. RSC Adv 4:3573-3580. https://doi.org/10.1039/c3ra46122j

Matassa S, Boon N, Verstraete W (2015) Resource recovery from used water: the manufacturing abilities of hydrogen-oxidizing bacteria. Water Res 68:467-478. https://doi.org/10.1016/j.watres.2014.10. 028

Matin A, Rahman F, Shafi HZ, Zubair SM (2019) Scaling of reverse osmosis membranes used in water desalination: phenomena, impact, and control; future directions. Desalination 455:135-157. https:// doi.org/10.1016/j.desal.2018.12.009

McDonald CA, Yang JY, Marathe V et al (2009) Combining results from lectin affinity chromatography and glycocapture approaches substantially improves the coverage of the glycoproteome. Mol Cell Proteomics 8:287-301. https://doi.org/10.1074/mcp.M800272MCP200

Meng F, Yang A, Wang H, Zhang G, Li X, Zhang Y, Zou Z (2018) Onestep treatment and resource recovery of high-concentration non- toxic organic wastewater by photosynthetic bacteria. Bioresour Technol 251:121-127. https://doi.org/10.1016/j.biortech.2017.12. 002

Miedzianka J, P ksa A, Aniołowska M (2012) Properties of acetylated potato protein preparations. Food Chem 133:1283-1291. https://doi. org/10.1016/j.foodchem.2011.08.080

Mishra BK, Arora A, Lata (2004) Optimization of a biological process for treating potato chips industry wastewater using a mixed culture of Aspergillus foetidus and Aspergillus Niger. Bioresour Technol 94: 9-12. https://doi.org/10.1016/j.biortech.2003.11.020

Mohammad AS (2013) Optimization of penicillin G acylase immobilization process by surface response methodology using central composite design. Appl Math 04:64-69. https://doi.org/10.4236/am. 2013.41012

Nagadomi H, Takahasi T, Sasaki K, Yang HC (2000) Simultaneous removal of chemical oxygen demand and nitrate in aerobic treatment of sewage wastewater using an immobilized photosynthetic bacterium of porous ceramic plates. World J Microbiol Biotechnol 16:5762. https://doi.org/10.1023/A:1008947416198

Ng LY, Ng CY, Mahmoudi E, Ong CB, Mohammad AW (2018) A review of the management of inflow water, wastewater and water reuse by membrane technology for a sustainable production in shrimp farming. J Water Process Eng 23:27-44. https://doi.org/10. 1016/j.jwpe.2018.02.020

Nunes SP, Culfaz-Emecen PZ, Ramon GZ, Visser T, Koops GH, Jin W, Ulbricht M (2020) Thinking the future of membranes: perspectives for advanced and new membrane materials and manufacturing processes. J Membr Sci 598:117761. https://doi.org/10.1016/j.memsci. 2019.117761

Park M, Anumol T, Simon J, Zraick F, Snyder SA (2017) Pre-ozonation for high recovery of nanofiltration (NF) membrane system: membrane fouling reduction and trace organic compound attenuation. J Membr Sci 523:255-263. https://doi.org/10.1016/j.memsci.2016. 09.051

Penña N, Gallego S, del Vigo F, Chesters SP (2013) Evaluating impact of fouling on reverse osmosis membranes performance. Desalin Water Treat 51:958-968. https://doi.org/10.1080/19443994.2012.699509

Pezeshk S, Ojagh SM, Rezaei M, Shabanpour B (2019) Fractionation of protein hydrolysates of fish waste using membrane ultrafiltration: investigation of antibacterial and antioxidant activities. Probiotics Antimicrob Proteins 11:1015-1022. https://doi.org/10.1007/ s12602-018-9483-y

Ponsano E, Pinto M, Garcia-Neto M, Lacava P (2004) Performance and color of broilers fed diets containing Rhodocyclus gelatinosus biomass. Braz J Poult Sci 6:237-242. https://doi.org/10.1590/S1516$635 \times 2004000400008$

Ponsano EHG, Paulino CZ, Pinto MF (2008) Phototrophic growth of Rubrivivax gelatinosus in poultry slaughterhouse wastewater. Bioresour Technol 99:3836-3842. https://doi.org/10.1016/j. biortech.2007.06.063

Pouvreau L, Gruppen H, Piersma SR, van den Broek LAM, van Koningsveld GA, Voragen AGJ (2001) Relative abundance and inhibitory distribution of protease inhibitors in potato juice from cv. Elkana. J Agric Food Chem 49:2864-2874. https://doi.org/10. 1021/jf010126v

Prachanurak P, Chiemchaisri C, Chiemchaisri W, Yamamotob K (2014) Biomass production from fermented starch wastewater in photobioreactor with internal overflow recirculation. Bioresour Technol 165:129-136. https://doi.org/10.1016/j.biortech.2014.03.119

Qi X, Ren Y, Tian E, Wang X (2017) The exploration of monochromatic near-infrared LED improved anoxygenic photosynthetic bacteria Rhodopseudomonas sp. for wastewater treatment. Bioresour Technol 241:620-626. https://doi.org/10.1016/j.biortech.2017.05. 202

Qiao M, Liu X, Song J-W, Yang T, Chen ML, Wang JH (2018) Improving the adsorption capacity for ovalbumin by functional 
modification of aminated mesoporous silica nanoparticles with tryptophan. J Mater Chem B 6:7703-7709. https://doi.org/10.1039/ C8TB02221F

Rajewska P, Janiszewska J (2017) The possibility for the use of ultrafiltration for the treatment of potato processing water. J Mach Constr Maintenance Probl Eksploat:131-139

Ramasamy DL, Puhakka V, Doshi B, Iftekhar S, Sillanpää M (2019) Fabrication of carbon nanotubes reinforced silica composites with improved rare earth elements adsorption performance. Chem Eng J 365:291-304. https://doi.org/10.1016/j.cej.2019.02.057

Ras M, Girbal-Neuhauser E, Paul E, Spérandio M, Lefebvre D (2008) Protein extraction from activated sludge: an analytical approach. Water Res 42:1867-1878. https://doi.org/10.1016/j.watres.2007. 11.011

Repaske R, Mayer R (1976) Dense autotrophic cultures of Alcaligenes eutrophus. Appl Environ Microbiol 32:592-597

Roslan J, Mustapa Kamal SM, Khairul KF, Abdullah N (2017) Assessment on multilayer ultrafiltration membrane for fractionation of tilapia by-product protein hydrolysate with angiotensin Iconverting enzyme (ACE) inhibitory activity. Sep Purif Technol 173:250-257. https://doi.org/10.1016/j.seppur.2016.09.038

Saejung C, Thammaratana T (2016) Biomass recovery during municipal wastewater treatment using photosynthetic bacteria and prospect of production of single cell protein for feedstuff. Environ Technol (United Kingdom) 37:3055-3061. https://doi.org/10.1080/ 09593330.2016.1175512

Sae-ung S, Boonamnuayvitaya V (2008) One-pot synthesis of organicinorganic hybrid mesoporous materials for the adsorption of formaldehyde vapor. Environ Eng Sci 25:397-406. https://doi.org/10. 1089/ees.2007.0011

Saidi S, Ben Amar R (2016) Valorisation of tuna processing waste biomass for recovery of functional and antioxidant peptides using enzymatic hydrolysis and membrane fractionation process. Environ Sci Pollut Res 23:21070-21085. https://doi.org/10.1007/s11356016-7334-5

Saikia D, Deka JR, Wu CE, Yang YC, Kao HM (2019a) pH responsive selective protein adsorption by carboxylic acid functionalized large pore mesoporous silica nanoparticles SBA-1. Mater Sci Eng C 94: 344-356. https://doi.org/10.1016/j.msec.2018.09.043

Saikia D, Deka JR, Wu CE et al (2019b) pH responsive selective protein adsorption by carboxylic acid functionalized large pore mesoporous silica nanoparticles SBA-1. Elsevier B.V

Salis A, Bhattacharyya MS, Monduzzi M, Solinas V (2009) Role of the support surface on the loading and the activity of Pseudomonas fluorescens lipase used for biodiesel synthesis. J Mol Catal B Enzym 57:262-269. https://doi.org/10.1016/j.molcatb.2008.09.015

Sangameshwar Barnes K, Mokhtari ZB, Amai T, Tanaka K (2013) Microbial production of poly(hydroxybutyrate) from $\mathrm{C} 1$ carbon sources. Appl Microbiol Biotechnol 97:1407-1424. https://doi.org/ 10.1007/s00253-012-4649-0

Sarkar B, Chakrabarti PP, Vijaykumar A, Kale V (2006) Wastewater treatment in dairy industries - possibility of reuse. Desalination 195:141-152. https://doi.org/10.1016/j.desal.2005.11.015

Sasaki K, Morikawa H, Kishibe T et al (2012) Practical removal of radioactivity from soil in Fukushima using immobilized photosynthetic bacteria combined with anaerobic digestion and lactic acid fermentation as pre-treatment. Biosci Biotechnol Biochem 76:18091814. https://doi.org/10.1271/bbb.120440

Sayari N, Sila A, Haddar A, Balti R, Ellouz-Chaabouni S, Bougatef A (2016) Valorisation of smooth hound (Mustelus mustelus) waste biomass through recovery of functional, antioxidative and antihypertensive bioactive peptides. Environ Sci Pollut Res 23:366-376. https://doi.org/10.1007/s11356-015-5244-6

Sert G, Bunani S, Yörükoğlu E, Kabay N, Egemen Ö, Arda M, Yüksel M (2017) Performances of some NF and RO membranes for desalination of MBR treated wastewater. J Water Process Eng 16: 193-198. https://doi.org/10.1016/j.jwpe.2016.11.009

Shahid MK, Kashif A, Rout PR, Aslam M, Fuwad A, Choi Y, Banu J R, Park JH, Kumar G (2020) A brief review of anaerobic membrane bioreactors emphasizing recent advancements, fouling issues and future perspectives. J Environ Manag 270:110909. https://doi.org/ 10.1016/j.jenvman.2020.110909

Shi J, Podola B, Melkonian M (2007) Removal of nitrogen and phosphorus from wastewater using microalgae immobilized on twin layers: an experimental study. J Appl Phycol 19:417-423. https://doi.org/ 10.1007/s10811-006-9148-1

Song X, Shi Z, Li X, Wang X, Ren Y (2019) Fate of proteins of waste activated sludge during thermal alkali pretreatment in terms of sludge protein recovery. Front Environ Sci Eng 13:13. https://doi. org/10.1007/s11783-019-1114-7

Steinhauer T, Marx M, Bogendörfer K, Kulozik U (2015) Membrane fouling during ultra- and microfiltration of whey and whey proteins at different environmental conditions: the role of aggregated whey proteins as fouling initiators. J Membr Sci 489:20-27. https://doi. org/10.1016/j.memsci.2015.04.002

Strætkvern KO, Schwarz JG (2012) Recovery of native potato protein comparing expanded bed adsorption and ultrafiltration. Food Bioprocess Technol 5:1939-1949. https://doi.org/10.1007/s11947010-0494-2

Surasani VKR, Tyagi A, Kudre T (2017) Recovery of proteins from Rohu processing waste using $\mathrm{pH}$ shift method: characterization of isolates. J Aquat Food Prod Technol 26:356-365. https://doi.org/10.1080/ 10498850.2016.1186130

Tavakoli O, Yoshida H (2006) Conversion of scallop viscera wastes to valuable compounds using sub-critical water. Green Chem 8:100 106. https://doi.org/10.1039/b507441j

Tham PE, Ng YJ, Sankaran R, Khoo KS, Chew KW, Yap YJ, Malahubban M, Aziz Zakry FA, Show PL (2019) Recovery of protein from dairy milk waste product using alcohol-salt liquid biphasic flotation. Processes 7:1-18. https://doi.org/10.3390/PR7120875

Tu J, Boyle AL, Friedrich H, Bomans PHH, Bussmann J, Sommerdijk NAJM, Jiskoot W, Kros A (2016) Mesoporous silica nanoparticles with large pores for the encapsulation and release of proteins. ACS Appl Mater Interfaces 8:32211-32219. https://doi.org/10.1021/ acsami.6b11324

Van Der Hoek JP, De Fooij H, Struker A (2016) Wastewater as a resource: strategies to recover resources from Amsterdam's wastewater. Resour Conserv Recycl 113:53-64. https://doi.org/10.1016/j. resconrec.2016.05.012

Venkata Mohan S, Lalit Babu V, Sarma PN (2008) Effect of various pretreatment methods on anaerobic mixed microflora to enhance biohydrogen production utilizing dairy wastewater as substrate. Bioresour Technol 99:59-67. https://doi.org/10.1016/j.biortech. 2006.12.004

Volova TG, Barashkov VA (2010) Characteristics of proteins synthesized by hydrogen-oxidizing microorganisms. Appl Biochem Microbiol 46:574-579. https://doi.org/10.1134/ S0003683810060037

Wallberg O, Jönsson AS, Wimmerstedt R (2003) Ultrafiltration of kraft black liquor with a ceramic membrane. Desalination 156:145-153. https://doi.org/10.1016/S0011-9164(03)00337-0

Wang L, Qi T, Zhang Y (2006) Novel organic-inorganic hybrid mesoporous materials for boron adsorption. Colloids Surf A Physicochem Eng Asp 275:73-78. https://doi.org/10.1016/j.colsurfa.2005.06.075

Washmon-Kriel L, Jimenez VL, Balkus KJ (2000) Cytochrome c immobilization into mesoporous molecular sieves. J Mol Catal B Enzym 10:453-469. https://doi.org/10.1016/S1381-1177(99)00123-X

Wen S, Liu H, He H, Luo L, Li X, Zeng G, Zhou Z, Lou W, Yang C (2016) Treatment of anaerobically digested swine wastewater by Rhodobacter blasticus and Rhodobacter capsulatus. Bioresour Technol 222:33-38. https://doi.org/10.1016/j.biortech.2016.09.102 
Wen-qiong W, Yun-chao W, Xiao-feng Z, Rui-xia G, Mao-lin L (2019) Whey protein membrane processing methods and membrane fouling mechanism analysis. Food Chem 289:468-481. https://doi.org/ 10.1016/j.foodchem.2019.03.086

Xiao K, Zhou Y (2020) Protein recovery from sludge: a review. J Clean Prod 249:119373. https://doi.org/10.1016/j.jclepro.2019.119373

Xie Z, Huang J, Xu X, Jin Z (2008) Antioxidant activity of peptides isolated from alfalfa leaf protein hydrolysate. Food Chem 111: 370-376. https://doi.org/10.1016/j.foodchem.2008.03.078

Xu C, Liu X, Xie B, Yao C, Hu W, Li Y, Li X (2016) Preparation of PES ultrafiltration membranes with natural amino acids based zwitterionic antifouling surfaces. Appl Surf Sci 385:130-138. https://doi.org/ 10.1016/j.apsusc.2016.05.084

Yang A, Zhang G, Yang G, Wang H, Meng F, Wang H, Peng M (2017) Denitrification of aging biogas slurry from livestock farm by photosynthetic bacteria. Bioresour Technol 232:408-411. https://doi.org/ 10.1016/j.biortech.2017.01.073

Yin Y, Fatufe AA, Blachier F (2011) Soya bean meal and its extensive use in livestock feeding and nutrition. Soybean Nutr. https://doi.org/ $10.5772 / 18823$

Zhang C, Sanders JPM, Bruins ME (2014a) Critical parameters in costeffective alkaline extraction for high protein yield from leaves. Biomass Bioenergy 67:466-472. https://doi.org/10.1016/j. biombioe.2014.05.020

Zhang W, Zhu Z, Jaffrin MY, Ding L (2014b) Effects of hydraulic conditions on effluent quality, flux behavior, and energy consumption in a shear-enhanced membrane filtration using box-Behnken response surface methodology. Ind Eng Chem Res 53:7176-7185. https://doi.org/10.1021/ie500117u

Zhang Q, Jin ZF, Hu ZC, Pan ZY (2015a) Biodegradation of m-cresol in alkaline wastewater by resting photosynthetic bacteria. Desalin
Water Treat 55:125-131. https://doi.org/10.1080/19443994.2014. 913992

Zhang W, Grimi N, Jaffrin MY, Ding L (2015b) Leaf protein concentration of alfalfa juice by membrane technology. J Membr Sci 489: 183-193. https://doi.org/10.1016/j.memsci.2015.03.092

Zhang W, Ding L, Grimi N, Jaffrin MY, Tang B (2017) Application of UF-RDM (ultafiltration rotating disk membrane) module for separation and concentration of leaf protein from alfalfa juice: optimization of operation conditions. Sep Purif Technol 175:365-375. https://doi.org/10.1016/j.seppur.2016.11.059

Zhang Q, Gao J, Qiu YR (2019) Removal of Ni (II) and Cr (III) by complexation-ultrafiltration using rotating disk membrane and the selective separation by shear induced dissociation. Chem Eng Process Process Intensif 135:236-244. https://doi.org/10.1016/j. cep.2018.12.005

Zhi R, Cao K, Zhang G, Zhu J, Xian G (2020) Zero excess sludge wastewater treatment with value-added substances recovery using photosynthetic bacteria. J Clean Prod 250:119581. https://doi.org/10. 1016/j.jclepro.2019.119581

Zhu GY, Zhu X, Wan XL, Fan Q, Ma YH, Qian J, Liu XL, Shen YJ, Jiang JH (2010) Hydrolysis technology and kinetics of poultry waste to produce amino acids in subcritical water. J Anal Appl Pyrolysis 88:187-191. https://doi.org/10.1016/j.jaap.2010.04.005

Zwijnenberg HJ, Kemperman AJB, Boerrigter ME et al (2002) Native protein recovery from potato fruit juice by ultrafiltration. Desalination 144:331-334. https://doi.org/10.1016/S00119164(02)00338-7

Publisher's note Springer Nature remains neutral with regard to jurisdictional claims in published maps and institutional affiliations. 